\title{
Secondary Metabolites and Biological Activity of Invasive Macroalgae of Southern Europe
}

\author{
Patrícia Máximo ${ }^{1, *(\mathbb{D})}$, Luísa M. Ferreira ${ }^{1}$, Paula Branco ${ }^{1}{ }^{(\mathbb{D})}$, Pedro Lima ${ }^{2,3}$ and Ana Lourenço ${ }^{1, *}$ \\ 1 LAQV-REQUIMTE, Departamento de Química, Faculdade de Ciências e Tecnologia, Universidade NOVA \\ de Lisboa, 2829-516 Caparica, Portugal; lpf@fct.unl.pt (L.M.F.); paula.branco@fct.unl.pt (P.B.) \\ 2 Sea4Us-Biotecnologia de Recursos Marinhos, Ltd., 8650-378 Sagres, Portugal; pedro.lima@sea4us.pt \\ 3 Nova Medical School/Faculdade de Ciências Médicas, Universidade Nova de Lisboa, Campo Mártires da \\ Pátria, 1169-056 Lisboa, Portugal \\ * $\quad$ Correspondence: psm@fct.unl.pt (P.M.); ana.lourenco@fct.unl.pt (A.L.); Tel.: +351-21-294-8500 (P.M. \& A.L.)
}

Received: 29 June 2018; Accepted: 31 July 2018; Published: 2 August 2018

\begin{abstract}
In this review a brief description of the invasive phenomena associated with algae and its consequences on the ecosystem are presented. Three examples of invasive algae of Southern Europe, belonging to Rodophyta, Chlorophyta, and Phaeophyta, were selected, and a brief description of each genus is presented. A full description of their secondary metabolites and biological activity is given and a summary of the biological activity of extracts is also included. In Asparagopsis we encounter mainly halogenated compounds. From Caulerpa, several terpenoids and alkaloids were isolated, while in Sargassum, meroterpenoids prevail.
\end{abstract}

Keywords: invasive species; Asparagopsis sp.; Caulerpa sp.; Sargassum sp.; chemistry and biological activity

\section{Introduction}

Alien species are plants, animals, or microbes that have been introduced and spread into new host regions, establishing populations that can become invasive if they interfere with the host ecosystem. These invasive species become established in natural or seminatural ecosystems, increasing in abundance and distribution and threatening biological diversity. They compete with native species, and usually have high reproductive rates assisted either by the lack of predators in the new environment or by the tolerance of a different range of environmental conditions. As a consequence, they are difficult to contain, harm biodiversity, and change the new host ecosystem [1].

Alien macroalgae are particularly likely to become invasive: their high reproductive rates, their production of toxic metabolites, and/or their perennial status make them more competitive than the native species, increasing the probability that they will become invasive. Several of these species periodically become a major problem, clogging waterways, fouling nets, and changing nutrient regimes in areas around fisheries, desalination facilities, and aquaculture systems [1]. They impact on local economies, such as fishery [2] and tourism.

The mechanism of invasion by macroalgae thus begins with transport (by means of fouling, ballast waters, or aquaculture), proceeds by establishment of the species (through biotic and abiotic factors), and ends with its spread and impact [3-7]. Management of this update problem requires adequate measures [8] and control procedures, such as mechanical means, biological control, and/or chemical remedies [9].

With global warming there is a general increase of the tendency of invasive episodes, this being a situation of concern especially for Southern Europe. The Mediterranean coast and Atlantic areas near Gibraltar are key points in the dynamics and spread of these phenomena. As an example, in 2016, several beaches in Gibraltar were interdicted by Dictyota invasions with direct impact on local 
tourism, and remediation and management costs. However, macroalgae have underlying potential. Their commercial use as a source of nutraceuticals, food additives, biofuel, antifouling agents, or pharmaceuticals could be a way to exploit these phenomena in a more profitable way $[4,10]$.

Thus, knowledge of the chemistry of these macroalgae is by no means out of date, as recent papers on the activity of algal extracts well document. Knowledge of their secondary metabolites and this review are also a starting point to the understanding of the chemistry of these species. There is a need, however, to fully characterize these invasive species in their new environment in order to make the most of their existence, and perform a strict correlation between metabolite and activity.

In this review we chose three genera of invasive species of the Mediterranean-Asparagopsis, Caulerpa, and Sargassum - as examples of the chemistry of red, green, and brown algae, respectively. Two of them-Asparagopsis and Caulerpa-are already signaled by the International Union for Conservation of Nature (IUCN) Centre for Mediterranean Cooperation [1].

The secondary metabolites of the chosen genus are presented and, when possible, the studied biological activities are given. Reference to their study as invasive specimens is also provided. A list of reports on the biological activity of extracts is also given. This review covers the literature up to 2017.

\section{Structural Characterization and Biological Activity}

In this paper a chemical and biological activity summary of three different genera of invasive species of Southern Europe is presented. The structural identification of the mentioned metabolites relies on the usual techniques such as NMR, IR, MS, and chemical transformations for the less recent publications. Although some of the studies include biological activities of the isolated metabolites, most of the papers only mention isolation and characterization.

\subsection{Asparagopsis}

Asparagopsis is a red seaweed genus of the family Bonnemaisoniaceae that has a diplohaplontic life cycle and a heteromorphic tetrasporophyte known as the "Falkenbergia" stage [11] Currently, only two species of this genus are accepted, $A$. armata and $A$. taxiformis, the former being endemic to the southern hemisphere and the latter being widely distributed in the tropics and subtropics [12]. Recently, a study of the lineages of this genus by DNA sequence was published [13].

Both species of this genus are native to Western Australia. A. armata is nowadays distributed throughout Europe in both the Atlantic and the Mediterranean basin, where it is highly invasive. A. taxiformis is invasive around the Indo-Pacific region, including Japan and Hawaii, and is currently widespread throughout the Mediterranean and along the Atlantic coast of Europe. While A. armata was probably introduced by maritime transport, A. taxiformis was probably introduced by oyster aquaculture [1].

Asparagopsis has been known to produce halogenated low-molecular-weight compounds [14-21].

We can also find reports on the presence of sterols in A. armata including 22-dehydrocholesterol, cholesterol, desmosterol, brassicasterol, 25-hydroxycholesterol, 25-hydroxy-24-methylcholesterol, fucosterol, $\beta$-sitosterol, liagosterol, and the hydroxylated sterols 1-4 represented in Figure 1 [22-24].

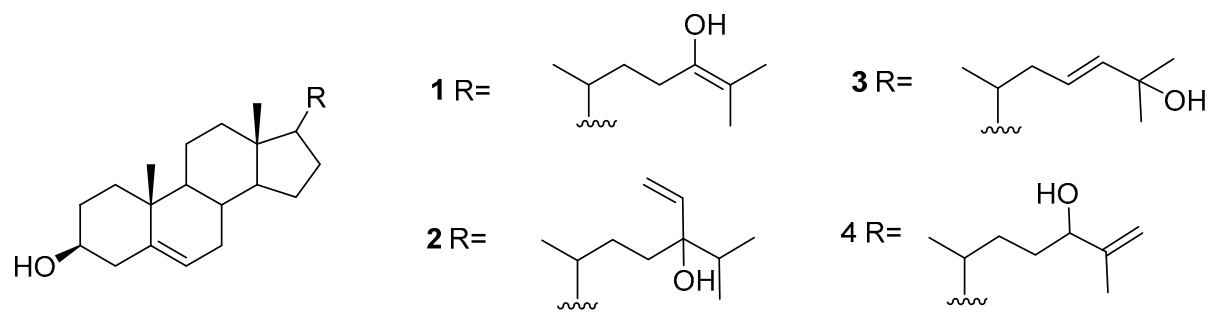

Figure 1. Hydroxylated sterols from A. armata. 
A more recent study consists of the identification of the two brominated cyclopentenones $\mathbf{5}$ and $\mathbf{6}$ from A. taxiformis (Figure 2) [25].<smiles>O=C1CC(O)(C(Br)Br)C(Br)=C1Br</smiles>

5<smiles>O=C1C(Br)=C(Br)[C@](O)(C(Br)Br)[C@H]1Br</smiles>

6

Figure 2. Brominated cyclopentenones from A. taxiformis.

Ecotoxicological activities of $\mathbf{5}$ and $\mathbf{6}$ against a marine bioluminescent bacterium (Vibrio fischeri) were used as an assessment of their role in the environment, revealing high toxicities for both compounds ( $\mathrm{EC}_{50}$ effective concentration, $0.16 \mu \mathrm{M}$ for 5 and 6). Additionally, both compounds were evaluated in antibacterial, antifungal, and cytotoxicity assays. Compounds 5 and $\mathbf{6}$ exhibited mild antibacterial activities against the human pathogen Acinetobacter baumannii.

\subsection{Caulerpa}

Green algae of the genus Caulerpa Lamouroux represent the single genus in the family Caulerpaceae, which consists of approximately 60 species worldwide, generally distributed in shallow-water tropical and subtropical marine habitats. One of its species, Caulerpa racemosa, also known as "sea grapes", is an edible marine green seaweed widely distributed throughout the South China Sea.

C. racemosa var. cylindrica is native to SouthWestern Australia, and is invasive in the Mediterranean [26-28] where its introduction is still speculative. Maritime traffic and aquarium trade are the most likely vectors. It can still be found in aquarium stores and is sold by internet retailers. C. taxifolia was accidentally introduced into the Mediterranean from a public aquarium in Monaco. Since then, it has spread rapidly due to its natural vegetative dispersal mechanism, its lack of natural grazers, and the ease of dispersion by boats, anchors, fishing nets, and aquaria [1].

We can find several reports on the chemistry of Caulerpa sp. These include the isolation of three squalene derivatives from C. prolifera [29] and fatty acids and sterols from C. chemnitzia, C. faridii, C. manorensis, C. racemosa, and C. taxifolia, including cholesterol, 24-methylcholesterol, 24-methyl-cholesta-7,22-diene-3 $\beta$-ol, 4,24-dimethyl-cholesta-5,22-diene-3 $\beta$-ol, and $\beta$-sitosterol [30].

From C. racemosa, fucosterol and the oxygenated sterols 7-10 in Figure 3 were isolated, together with both C-24 epimers of saringosterol 2 [30,31].
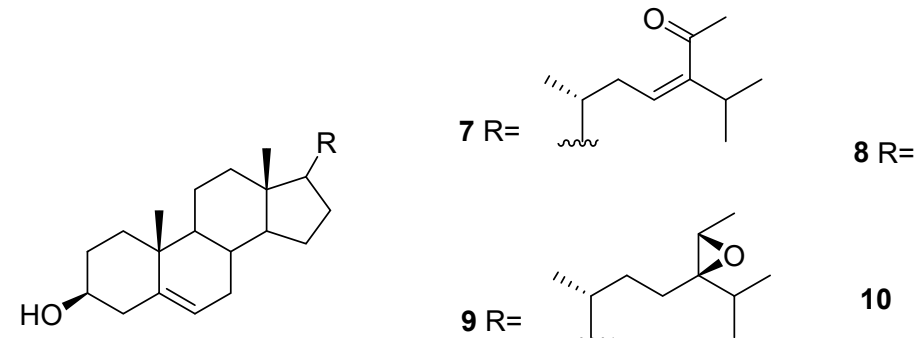<smiles>CC(C)/C=C/C(=O)C(C)C</smiles><smiles>[R]O[Na]</smiles>

10

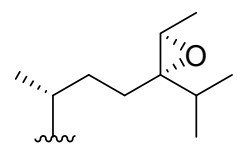

Figure 3. Oxygenated sterols from C. racemosa.

From C. racemosa, several varied metabolites were obtained by Yang et al. [31]. These include trans-phytol, trans-phytylacetate, $\alpha$-tocopherolquinone, and the metabolites 11-17 in Figure 4. 


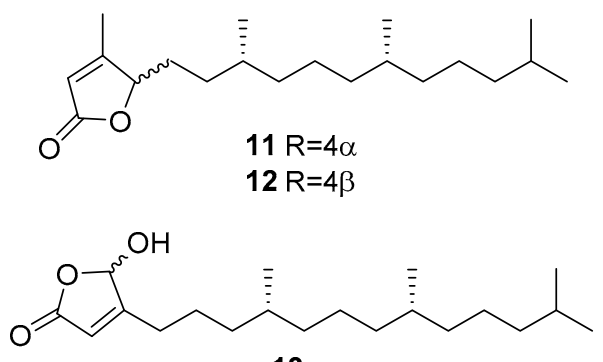

13<smiles>CC1=C(CCC(=O)OC/C=C(\C)CCC[C@H](C)CCC[C@H](C)CCCC(C)C)C(=O)NC1=O</smiles><smiles>Cc1cc(C)cc(Oc2c(C)c(C)c3c(c2C)CC[C@](C)(CCC[C@H](C)CCC[C@H](C)CCCC(C)(C)O)O3)c1</smiles><smiles>CC(=O)[C@]1(O)C(C)=C(C)C(=O)[C@]12CC(C)(CCC[C@H](C)CCC[C@H](C)CCCC(C)C)O2</smiles><smiles>[3H][3H]</smiles>

Figure 4. Metabolites from C. racemosa.

The enzyme inhibitory activities of all the compounds were evaluated in vitro against PTP1B (protein tyrosine phosphatase 1B) and related PTPs (protein phosphatases) (TCPTP (T-cell PTP), CDC25B (cell division cycle 25 homolog B), LAR (leukocyte antigen-related phosphatase), SHP-1 (src homology phosphatase-1), and SHP-2 (src homology phosphatase-2)). Compounds 14, trans-phytol, trans-phytylacetate, $\alpha$-tocopherolquinone, 16, and 17 and the sterols 7, 8, and $24 R$ saringosterol 2 and 10 exhibited different levels of PTP1B inhibitory activity with IC $_{50}$ (inhibitory concentration) values ranging from 2.30 to $50.02 \mu \mathrm{M}$. Of these compounds, 14, $\alpha$-tocopherolquinone, and 7 showed the most potent inhibitory activities towards PTP1B with $\mathrm{IC}_{50}$ values of $2.30,3.85$, and $3.80 \mu \mathrm{M}$, respectively. More importantly, the potent PTP1B inhibitors 14, $\alpha$-tocopherolquinone, and 7 also displayed high selectivity over the highly homologous TCPTP and other PTPs. The neuroprotective effects of the compounds against A $\beta 25-35$ (amyloid $\beta$-peptide fragment 25-35)-induced cell damage in SH-SY5Y (neuroblastoma cell line) cells, a widely used neuroblastoma cell line for study of neurodegenerative disease, were also investigated. Compounds 17, 7, and 8 exhibited significant neuroprotective effects against A $325-35$-induced SH-SY5Y cell damage with $11.31-15.98 \%$ increases in cell viability at $10 \mu \mathrm{M}$. In addition, the cytotoxic activities of the isolated compounds were tested against the human cancer cell lines A-549 (human lung carcinoma) and HL-60 (promyelocytic leukemia cells). Only the mixture 
of 11 and 12, 16, and $\alpha$-tocopherolquinone exhibited moderate cytotoxicity against HL-60, and $\alpha$-tocopherolquinone exhibited weak cytotoxicity against A-549 [31].

From C. racemosa we can also find two prenylated $p$-xylenes [32] 18 and 19 and racemosins A 20 and B 21 [33] (Figure 5).<smiles>Cc1ccc(C)c(/C=C/C(C)(C)O)c1/C=C/C(C)(C)O</smiles>

18<smiles>COC(=O)/C(=C1/C(=O)Nc2ccccc21)c1[nH]c2ccccc2c1C</smiles>

20<smiles>CC(C)=C[C@H]1c2c(C)ccc(C)c2[C@@H](O)[C@@H]1C(C)(C)O</smiles>

19<smiles>COC(=O)c1cc2c3ccccc3[nH]c2c2c1[nH]c1ccccc12</smiles>

21

Figure 5. Metabolites from C. racemosa.

From C. prolifera [34], caulerpin 22 was isolated (Figure 6).<smiles>COC(=O)c1cc2ccccc2c(C(=O)OC)cc2[nH]c3ccccc3[nH]c1=2</smiles>

22

Figure 6. Metabolite from C. prolifera.

In in vitro bioassays, the compounds 18 and 19 exhibited a broad spectrum of antifungal activity against Candida glabrata, Trichophyton rubrum, and Cryptococcus neoformans with $\mathrm{MIC}_{80}$ (minimum inhibitory concentration) values between 4 and $64 \mu \mathrm{g} / \mathrm{mL}$ when compared to amphotericin B (MIC 80 values of $2.0,1.0$, and $4.0 \mu \mathrm{g} / \mathrm{mL}$, respectively) as a positive control and showed no growth inhibition activity against the tumor cells HL60 and A549 [32].

The biological activity of compounds 20-22 was tested in a neuroprotective bioassay using A $325-35$-induced neurotoxicity in SH-SY5Y cells. Compound 22 showed significant neuroprotection ( $14.6 \%$ increase in cell viability) at the concentration of $10 \mu \mathrm{M}$, while compounds 20 and 21 showed moderate/weak neuroprotective activity with $5.5 \%$ and $8.1 \%$ increase in cell viability $(10 \mu \mathrm{M})$, respectively, when compared to EGCG (epigallocatechin gallate), $16.57 \%$ increase at $10 \mu \mathrm{M}$ ) as the positive control [33].

On the terpenoid constituents of this genus we can find reports on monoterpenes [35,36]; the sesquiterpenes 23-39 (Figure 7, Table 1), isolated from several species [35-39]; the diterpene $\mathbf{4 0}$ from C. trifaria [40]; and the diterpenes $\mathbf{4 1 - 5 4}$ from C. brownii [41,42] (Figure 8). 


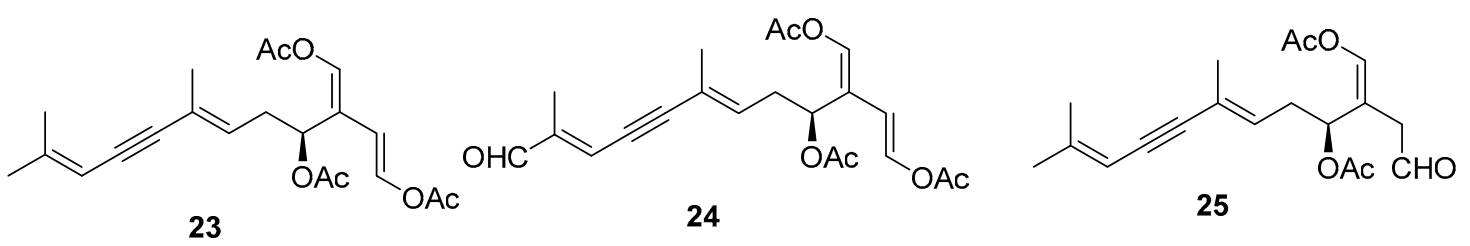<smiles>CCOC(=O)OC=CC(=COC(C)=O)C(CC=C(C)C#CC1OC1(C)C)OC(C)=O</smiles><smiles>CC(=O)OC/C=C(/C=O)CCC1C(C)=CCCC1(C)C</smiles>

29<smiles>C=C1CCCC(C)(C)C1CC/C(C=COC(C)=O)=C\OC(C)=O</smiles>

30<smiles>C=C1CCCC(C)(C)C1CC/C(C=O)=C\C=O</smiles>

31<smiles>C=C1CCCC(C)(C)C1CCC1=CC(O)OC1=O</smiles>

32<smiles>CC(=O)O/C=C/C(=C/OC(C)=O)CCC1C(C)=CCCC1(C)C</smiles>

33<smiles>CC(=O)OC=CC(=COC(C)=O)C(CC1C(C)=CCCC1(C)C)OC(C)=O</smiles>

${ }_{34}{ }^{\mathrm{AcO}}$<smiles>CC(=O)O/C=C/C(C=O)=C\CC1C(C)=CCCC1(C)C</smiles>

35<smiles>CC1=CCCC(C)(C)C1C/C=C(/C=O)CC=O</smiles>

36<smiles>CC(=O)OC/C(=C/CC1C(C)=CCCC1(C)C)CC=O</smiles>

37<smiles>[R]OCC(C=COC(C)=O)=CCC1C(C)=CCCC1(C)C</smiles>

$38 \mathrm{R}=\mathrm{C}_{16} \mathrm{H}_{31} \mathrm{O}$

$39 \mathrm{R}=\mathrm{C}_{16} \mathrm{H}_{29} \mathrm{O}$

Figure 7. Sesquiterpenes from Caulerpa sp.

Table 1. Sesquiterpenes from Caulerpa sp.

\begin{tabular}{ccc}
\hline Species & Compounds & Biological Activity \\
\hline C. ashmeadii [39] & $\mathbf{3 4 - 3 9}$ & Feeding preference, antimicrobial, ichthyotoxicity \\
C. bikinensis [38] & $\mathbf{3 0 - 3 2}$ & Feeding deterrents \\
C. flexilis var. muelleri [35] & $\mathbf{2 9 , 3 3}$ & - \\
C. prolifera [37] & $\mathbf{2 5}$ & - \\
C. taxifolia [36] & $\mathbf{2 6 - 2 8}$ & - \\
\hline
\end{tabular}


<smiles>CC(=O)O/C=C/C(=C/OC(C)=O)CC[C@H]1C(C)=CC[C@H]2[C@@H](C)CCC[C@@H]21</smiles><smiles>CC(=O)O/C=C/C(=C/OC(C)C)CC/C=C(\C)CC[C@@H]1C(C)(C)CCC[C@]1(C)O</smiles>

43<smiles>CC(=O)O/C=C/C(=C/OC(C)=O)CC/C=C(\C)CC[C@H]1C(C)=CCCC1(C)C</smiles>

45<smiles>[Z17]=C(/C=C(\CC/C=C(/CO)COC(C)=O)CC[C@@H]1C(C)=CCCC1(C)C)OC=O</smiles>
47<smiles>[R]C(=O)OC/C=C(\C)CC/C=C(\C)CCC1C(C)=CCCC1(C)C</smiles><smiles>[R]OC/C=C(\C)CC/C=C(\C)CCC1C(C)=CCCC1(C)C</smiles>

$41 \mathrm{R}=\mathrm{H}$

$42 \mathrm{R}=\mathrm{Ac}$<smiles>CC(=O)OC/C=C(\CC/C=C(\C)CC[C@H]1C(C)=CCCC1(C)C)COC(C)=O</smiles>

44<smiles>CC1=CCCC(C)(C)[C@H]1CC/C(C)=C/CC/C(C=O)=C\C=O</smiles>

46<smiles>CC(=O)O/C=C/C(C=O)(CC/C=C(\C)CC[C@@H]1C(C)=CCCC1(C)C)OC(C)=O</smiles>

48

$$
\begin{aligned}
& \mathrm{R}=\mathrm{C}_{19} \mathrm{H}_{31} \\
& \mathrm{C}_{19} \mathrm{H}_{29} \\
& \mathrm{C}_{17} \mathrm{H}_{33} \\
& \mathrm{C}_{17} \mathrm{H}_{31} \\
& \mathrm{C}_{17} \mathrm{H}_{29} \\
& \mathrm{C}_{15} \mathrm{H}_{25}
\end{aligned}
$$<smiles>CC(C)=CCC/C(C)=C/CC/C(C)=C/CC/C(C=O)=C\C=O</smiles>

50<smiles>CC(=O)O/C=C/C(=C/OC(C)=O)CC/C=C(\C)CC/C=C(\C)CCC=C(C)C</smiles>

52<smiles>CC(=O)OCC(=CC=O)CCC=C(C)CCC=C(C)CCC=C(C)C</smiles>

54

Figure 8. Diterpenes from Caulerpa sp. 
A study [39] on the feeding preference by herbivorous fishes on several species of caulerpa led to isolation of 34-39 from C. ashmeadii. Compounds 34 and 36-39, along with the alkaloid caulerpin 22, were tested for field feeding preference, antimicrobial activity (against the marine fungus Lagenidium callinectes, and the bacteria Vibrio leignathi, V. phosphoreum, and SK13 (Gram-positive spore-forming bacteria requiring $\mathrm{Mn}$ for growth)), and ichthyotoxicity. All compounds except compounds 38 and 39 showed antimicrobial activity toward at least one marine bacterium. Compounds 36 and 37 also showed activity toward all three bacteria. All metabolites, except the fatty esters $\mathbf{3 8}$ and 39 and caulerpin 22, were toxic to damselfish within $1.5 \mathrm{~h}$. Compounds 36 and 37 again showed the highest degree of biological activity in this assay.

From C. bikinensis, compounds 30-32 were isolated and tested as feeding deterrents [38]. The diacetate $\mathbf{3 0}$ and the dialdehyde $\mathbf{3 1}$ were found to be toxic to the Pacific damselfish Pomacentrus phillipinus at the 10 and $5 \mu \mathrm{g} / \mathrm{mL}$ levels. Feeding deterrence effects were reliably produced from 30 and 31 when tested at $1000 \mathrm{ppm}$ levels against similar herbivorous fishes. The cytotoxicities of these compounds against the fertilized egg of the Pacific sea urchin Lytechinus pinctus were also measured. Again, 30 and 31 showed $\mathrm{ED}_{50}$ (effective dose) values of 2 and $1 \mu \mathrm{g} / \mathrm{mL}$. The activities noted for these metabolites reinforce their likely roles in nature as agents of chemical defense.

From C. flexilis var. muelleri, compounds $\mathbf{2 9}$ and $\mathbf{3 3}$ were isolated. No absolute configuration was determined for 33 [35].

From C. prolifera, 25 was isolated and its absolute configuration determined as $S$ [37].

A study of C. taxifolia from Cap Martin, Côte d'Azur, at the time considered an invasive species,

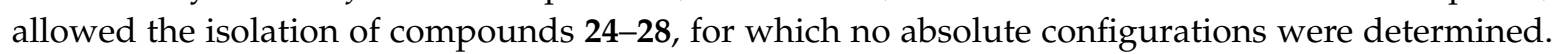
The proposed configurations were based on biosynthetic considerations [36].

From a larger study on algae of the order Caulerpales, diterpene 43 was isolated from C. brownii. [41]. Compound $\mathbf{4 3}$ had already been tested for biological activities. It showed antibacterial activity towards the pathogenic bacteria Staphylococcus aureus and Bacilus subtilis. It was also tested against marine bacteria and was found to be inhibitory towards Vibrio harveyi and V. leiognathi. It is also active against E. coli and V. anguillarum [41]. Handley reported the isolation of diterpenes 41-54 from branched and unbranched specimens of $C$. brownii and compound $\mathbf{5 0}$ was reported for the first time as a natural product [42].

From C. trifaria, diterpene $\mathbf{4 0}$ was isolated and the depicted configuration is proposed [40].

\subsection{Sargassum}

Sargassum is a genus of brown seaweeds with tropical and subtropical distribution, existing in all oceans. It is a large genus, comprising over 350 species. Some of its species are used in food in Japan and Korea, such as S. fusiforme and S. muticum. Due to air vesicles, S. natans and S. fluitans form large floating masses. S. muticum is invasive in the Mediterranean [43,44] and in Western Europe [45], and seems to have been introduced by the business of oyster culture [46].

A recent review on the therapeutic potential and health benefits of these species has been published [47].

We can find several reports on the isolation of sterols (Figure 9) from Sargassum sp.

From S. asperifolium [48], saringosterol 2 and 60 were isolated.

From S. carpophyllum [49], $\mathbf{6 1}$ and $\mathbf{6 2}$ were isolated, together with fucosterol, 24-ethylcholesta-4, 24(28)-dien-3,6-dione, 56, 57, 9, and 10. All compounds were tested for bioactivity of inducing morphological deformation of $P$. oryzae mycelia, and cytotoxic activity against several cultured cancer cell lines (P388 (mouse lymphocytic leukemia), HL-60, MCF-7 (breast adenocarcinoma), HCT-8 (human ilececal cancer), 1A9 (human ovarian cancer), HOS (human bone tumor), PC3 (human prostate cancer)).

The data showed that all the steroids exhibited activities causing morphological abnormality of P. oryzae mycelia. Fucosterol and 24-ethylcholesta-4,24(28)-dien-3,6-dione exhibited significant cytotoxicity toward P388 cancer cells, whereas $\mathbf{6 1}$ and $\mathbf{5 6}$ showed mild activity against the growth of HL-60 cancer cells. In the antitumor screen using a panel of human cell lines only the epoxy sterol 
10 showed some cytotoxicity against several human cell lines. Compounds $\mathbf{6 2}, \mathbf{9}$, and $\mathbf{1 0}$ were also evaluated for HIV (Human immunodeficiency virus) growth inhibition activity in H9 lymphocytes. The $\mathrm{EC}_{50}$ and $\mathrm{IC}_{50}$ values for 9 were 0.500 and $0.975 \mathrm{mg} / \mathrm{mL}$, whereas 62 and 10 were inactive.<smiles>[R]C1CCC2C3CC=C4CC(O)CCC4(C)C3CCC12C</smiles><smiles>CC(C)CCC(=CCO)C(C)C</smiles><smiles>CC(C)CCC(=O)C(C)C</smiles>

$56 \mathrm{R}=$<smiles>C=CC(O)(CCC(C)C)C(C)C</smiles><smiles>CC(C)C=CC(C)C1CCC2C(=O)C34CC(O)CCC3(C)C1CCC2C4C</smiles>

59<smiles>CC(C)C(=CCC1CCC2C3CC=C4CC(O)CCC4(C)C3CCC12C)C(C)O</smiles>

61<smiles>C/C=C(\CCC(C)C1CCC2C3CC=C4C(=O)C(O)CCC4(C)C3CCC12C)C(C)C</smiles>

63<smiles>C=CC(CCC(C)C1CCC2C3CC=C4C[C@@H](O)CC[C@]4(C)C3CCC12C)C(C)C</smiles>

65<smiles>C=CC(O)(CCC(C)C1CCC2C3CCC4=CC(=O)CCC4(C)[C@H]3CC[C@]12C)C(C)C</smiles>

60<smiles>C/C=C(/CCC(C)C1CCC2C3CCC4OC(=O)CC4(C)C3CCC12C)C(C)C</smiles>

62<smiles>C/C=C(/CCC(C)C1CCC2C3CCC4=CC(=O)CCC4(C)C3CCC12C)C(C)C</smiles>

64<smiles>CC(C)CCCC(C)C1CC=C2C3CC=C4CC(O)CCC4(C)C3CCC21C</smiles>

66

Figure 9. Sterols from Sargassum sp.

From S. fusiforme, fucosterol [50,51], both C-24 epimers of saringosterol 2 [51] and 55-59 were isolated [51]. Fucosterol was shown to possess antidepressant and anticonvulsional effects [50]. Compounds 55-59, fucosterol, and both C-24 epimers of saringosterol 2 were tested as LXR (liver 
X receptor) agonists: $24 S$-saringosterol 2 acted as a selective LXR $\beta$ agonist and was found to be potentially useful as a natural cholesterol lowering agent [51].

From S. oligoscystum [52], cholesterol, 22-dehydrocholesterol, fucosterol, both C-24 epimers of saringosterol 2, and 55, 56 and 58 were isolated.

From S. thunbergii [53], 63 was isolated, together with 3, and 64-66. Compound 63 exhibited significant inhibitory activity against human PTP1B with an IC 50 value of $2.24 \mu \mathrm{g} / \mathrm{mL}$.

From the genus Sargassum we can also find reports on the isolation of quinones and hydroquinones, chromenes, and varied structures.

Quinones and hydroquinones

We can find several reports on the isolation of quinones and hydroquinones from Sargassum sp. [54-65]. Their structures are in Figure 10 and occurrences are in Table 2.

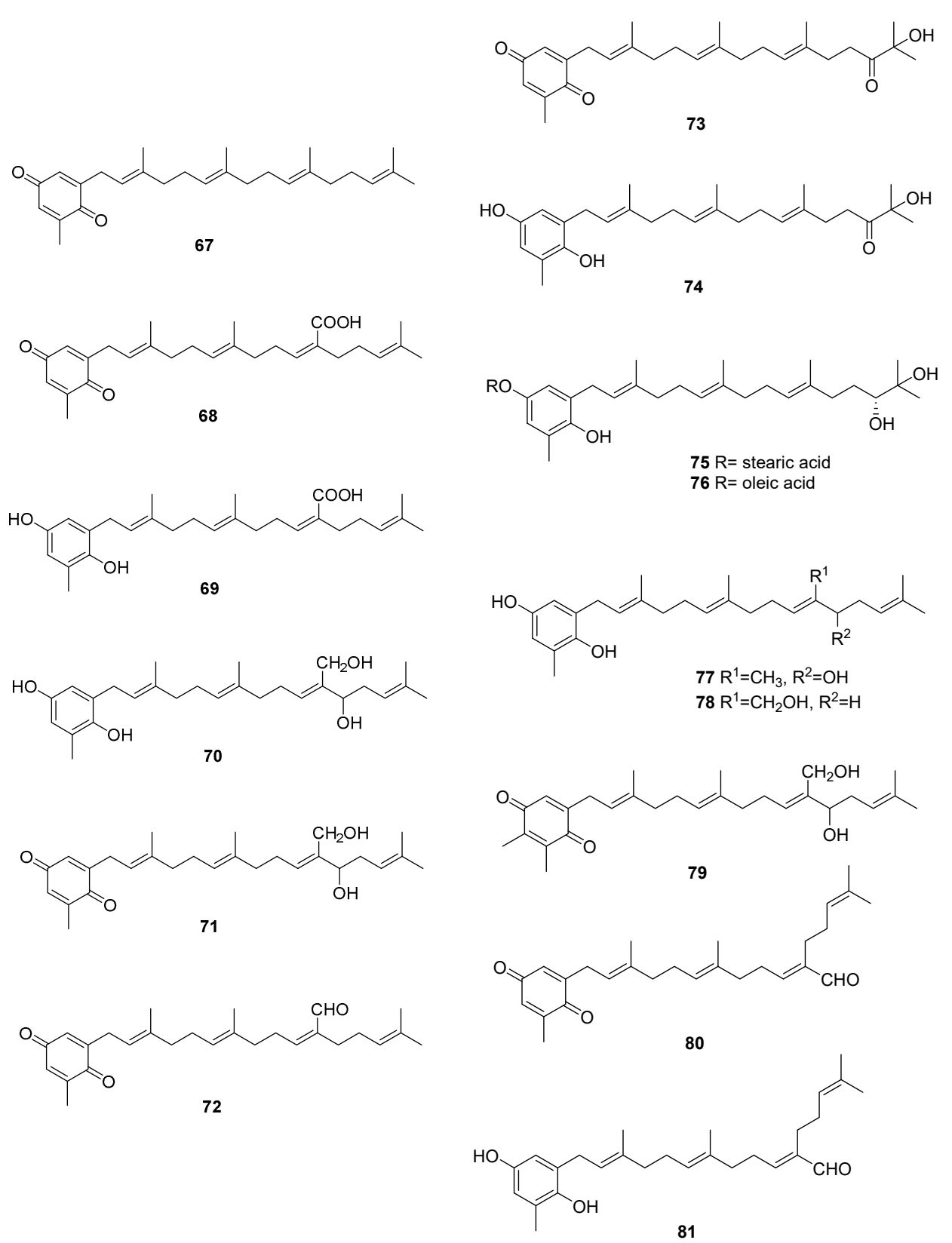

Figure 10. Cont. 


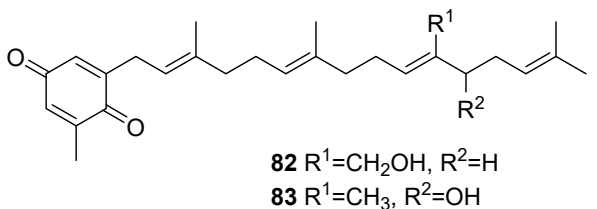<smiles>CC(C)=CCCC1=CC(C/C(C)=C/CC/C(C)=C/CC2=CC(=O)C=C(C)C2=O)OC1=O</smiles><smiles>C=C(C)[C@H](O)CC/C(=C/CC/C(C)=C/CC/C(C)=C/Cc1cc(O)cc(C)c1O)C(=O)O</smiles>

85<smiles>C=C(CC/C=C(\CCC=C(C)C)C(=O)O)[C@H](O)CC/C(C)=C/Cc1cc(O)cc(C)c1O</smiles><smiles>CC(C)=CCC/C(=C\CC/C(C)=C/CC[C@](C)(O)CCc1cc(O)cc(C)c1O)C(=O)O</smiles><smiles>C=C(C)C(=O)CC/C(=C\CC/C(C)=C/CC/C(C)=C/Cc1cc(O)cc(C)c1O)C(=O)O</smiles><smiles>CC(C)=CCC/C(C)=C/C(O)C(O)/C(C)=C/CC/C(C)=C/Cc1cc(O)cc(C)c1O</smiles><smiles>CC(C)=CCC/C(C)=C/C(O)C/C(C)=C/CC/C(C)=C/Cc1cc(O)cc(C)c1O</smiles><smiles>CC(C)=CCCC(C)(O)/C=C/C/C(C)=C/CC/C(C)=C/Cc1cc(O)cc(C)c1O</smiles><smiles>COC(/C=C(\C)CCC=C(C)C)C/C(C)=C/CC/C(C)=C/CC1=CC(=O)C=C(C)C1=O</smiles><smiles>CC(C)=CCCC(C)(C)/C=C/C/C(C)=C/CC/C(C)=C/CC1=CC(=O)C=C(C)C1=O</smiles><smiles>CC(C)=CCC/C(C)=C/C(O)C(O)/C(C)=C/CC/C(C)=C/CC1=CC(=O)C=C(C)C1=O</smiles><smiles>CC(C)=CCC/C(C)=C/C(O)C(O)/C(C)=C/CC/C(C)=C/CC1=CC(=O)C(C)=C(C)C1=O</smiles><smiles>CC(C)=CC=C(CCC=C(C)CCCC(C)(O)CCC(C)=CCCC(C)=CCCC(C)(O)CCC1=CC(=O)C=CC1=O)C(=O)C(O)C=C(C)C</smiles>

97

Figure 10. Quinones and hydroquinones from Sargassum sp.

From S. elegans, 68, 69, and 72 were isolated by electrochemistry-guided fractioning and their antioxidant potential was evaluated [54].

From S. fallax [55], 67-71 were isolated. Sargaquinone 67 was isolated as a mixture with sargaquinoic acid 68 . Both 68 and 69 were found to display moderate antitumor activity when tested against P388 cells. They displayed only weak activity against Bacillus subtilis. 
From S. herophyllum [56], 67, 69, and $\mathbf{7 2}$ were isolated. They displayed moderate antiplasmodial activity against $P$. falciparum.

Table 2. Quinones and hydroquinones from Sargassum sp.

\begin{tabular}{|c|c|c|}
\hline Species & Compounds & Biological Activity \\
\hline S. elegans [54] & $68,69,72$ & Antioxidants \\
\hline S. fallax [55] & $67-71$ & Antitumour against P388 \\
\hline S. herophyllum [56] & $67,69,72$ & Antiplasmodial activity \\
\hline S. michranthum [57] & $73-76$ & $\begin{array}{l}\text { Antioxidants, radical scaveging, inhibitory effect on lipid } \\
\text { peroxidation, antiproliferative against 26-L5, cytotoxicity }\end{array}$ \\
\hline S. paradoxum [58] & $67-71,77-83$ & Antibacterial \\
\hline S. sagamium var. yezoense [59] & $68,69,80,84$ & - \\
\hline S. sagamium $[64,65]$ & 68 & $\begin{array}{l}\text { Anticholinesterase activity, proapoptotic, and } \\
\text { anti-inflammatory }\end{array}$ \\
\hline S. serratifolium [60] & 68,80 & - \\
\hline S. siliquastrum [61] & 96,97 & Radical scavenging \\
\hline S. thunbergii $[62,63]$ & 68,69 & Osteoblastogenesis-enhancing abilities \\
\hline S. tortile [66] & $67,89-95$ & - \\
\hline S. yezoense $[67,68]$ & $68,69,85-88$ & $\begin{array}{l}\text { Transcriptional activity of PPARs (Peroxisome } \\
\text { proliferator-activated receptors), antidiabetic potential }\end{array}$ \\
\hline
\end{tabular}

From S. michranthum [57], 73-76 were isolated. Compounds 74-76 displayed strong antioxidant activity, such as an inhibitory effect on NADPH-dependent lipid peroxidation in rat liver microsomes and radical-scavenging effect on DPPH (1,1-diphenyl-2-picrylhydrazyl). The inhibitory effect on lipid peroxidation was shown to be the same or stronger than that of the positive control, $\alpha$-tocopherol. The authors identify the absence or presence of an unsaturated cis carbon-carbon double bond in the long-chain fatty acid ester moiety of $\mathbf{7 5}$ and $\mathbf{7 6}$ as responsible for the large difference in the inhibitory activity. Both compounds were found to have moderate radical-reducing effect on DPPH at a dose of each sample of $100 \mathrm{mg} / \mathrm{mL}$. Based on these preliminary results, the author suggest that the hydroquinone moiety of $\mathbf{7 4}$ must participate in antioxidant activity, while in compounds $\mathbf{7 5}$ and 76, hydrolysis of their ester group occurs first, and the resulting $\mathbf{7 4}$ may owe this activity. Antiproliferative activity of 74-76 against Colon 26-L5 cell was also evaluated. Compounds $\mathbf{7 4}$ and $\mathbf{7 6}$ showed relatively strong cytotoxic activity while moderate activity in the case of 75 was observed.

From S. paradoxum [58], 67-71 together with 77-83 were identified by HPLC-NMR and HPLC-MS. Some of the compounds were isolated by bioguided fractioning and tested for their biological activity. Compared to the antibiotic ampicillin, the isolated compounds were far less potent against S. aureus and S. pyogenes. However, compounds $69,71,80$, and 260 were more potent against $P$. aeruginosa than ampicillin. There was no difference in activity between compounds with the hydroquinone or the $p$-benzoquinone moieties. The activity observed for sargaquinone 67 , the simplest of the meroditerpenoids isolated, suggests that the unsubstituted meroditerpenoid skeleton is responsible for the activity against $P$. aeruginosa. The addition of an alcohol group at position $12^{\prime}$ or $20^{\prime}(70,77$, 78,82 , and 83) appears to reduce the activity against $P$. aeruginosa, but increases the activity against S. pyogenes. Finally, incorporation of a carboxylic acid at position C-20' (69 and 68) gives rise to activity against S. aureus and S. aureus MRSA Methicillin-resistant Staphylococcus aureus).

From S. sagamium var. yezoense [59], 68, 69, 80, and 84 were isolated and from S. sagamium, 68 was isolated [64]. Its anticholinesterase activity and potential in Alzheimer's disease is described [64]. The proapoptotic [65] and anti-inflammatory activities [69] of 68 are also documented. 
From S. serratifolium [60], 68 and 80 were isolated and from S. siliquastrum [61], 96 and $\mathbf{9 7}$ were isolated. Compound $\mathbf{9 6}$ showed radical-scavenging activity in DPPH assays.

From S. thunbergii [62,63], sargaquinoic acid 68 and sargahydroquinoic acid 69 were isolated. Since $S$. thunbergii was shown to inhibit adipogenesis in pre-adipocytes while enhancing osteoblast differentiation of pre-osteoblasts, and $\mathbf{6 8}$ and $\mathbf{6 9}$ were isolated in a bioguided study, the authors suggest that these two compounds possess osteoblastogenesis-enhancing abilities [63].

From S. tortile [66], 67 and 89-95 were isolated.

Compounds 68 and 69 were also isolated from S. yezoense [67]. Their effect on the transcriptional activity of PPARs (Peroxisome proliferator-activated receptors) was studied. The authors suggest that both compounds could be possible candidates for the treatment of type-2 diabetes and dyslipidemia. From S. yezoense [68], 85-88 were also isolated. Their antidiabetic potential was also evaluated.

\subsection{Chromenes}

We can also find reports on the isolation of chromenes [58,60,62,64,65,70-77]. Their structures are in Figure 11 and occurrences are in Table 3.<smiles>CC(C)=CCCC(C)=CCCC(C)=CCCC1(C)CCc2cc(O)cc(C)c2O1</smiles>

98<smiles>CC(C)=CCCC(=CCCC(C)=CCCC1(C)CCc2cc(O)cc(C)c2O1)C(=O)O</smiles>

99<smiles>CC(C)=CC(O)C(=O)C(C)=CCCC(C)=CCCC1(C)CCc2cc(O)cc(C)c2O1</smiles><smiles>CC(C)=CCC/C(C)=C/CCC1(C)CCc2cc(O)cc(C)c2O1</smiles>

101<smiles>[Y]C(O)C(O)C=C(C)C</smiles>

102<smiles>[Y]C(O)[C@H](O)C=C(C)C</smiles>

103<smiles>[Y][C@H](O)C(=O)C=C(C)C</smiles>

Figure 11. Cont. 


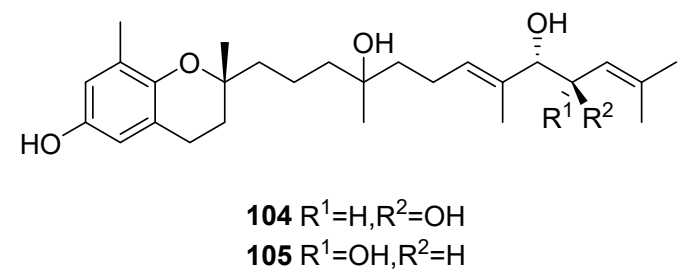<smiles>CC(=CCCC1(C)CCc2cc(O)cc(C)c2O1)CCCC(C)C(=O)O</smiles>

106<smiles>CC(C)=CCCC1(C)CCc2cc(O)cc(C)c2O1</smiles>

109<smiles>CCCC=C(C)[C@@H](O)CC=C(C)C</smiles>
110<smiles>CCCC=C(C)[C@@H](OC)[C@@H](O)C=C(C)C</smiles>
111<smiles>CCCCC=C(C)C(=O)C(O)C=C(C)C</smiles>
112<smiles>[Y]CCCC(C)C(=O)C(O)C=C(C)C</smiles><smiles>C/C(=C\CC[C@]1(C)CCc2cc(O)cc(C)c2O1)CC/C=C(\C)C(=O)O</smiles>

$107 \mathrm{R}=\mathrm{CHO}$

$108 \mathrm{R}=\mathrm{CH} 2 \mathrm{OH}$
113<smiles>[Y]C/C=C\C(C)C(=O)[C@@H](O)CC(C)C</smiles>

114<smiles>[Y]CCCC(C)C(=O)[C@@H](O)C=C(C)C</smiles>

115<smiles>CCCC=C(C)[C@@H](O)C(=O)C=C(C)C</smiles><smiles>[R]C(C=C(C)C)/C(C)=C/CC/C(C)=C/CC[C@]1(C)CCc2cc(O)cc(C)c2O1</smiles>

Figure 11. Cont. 


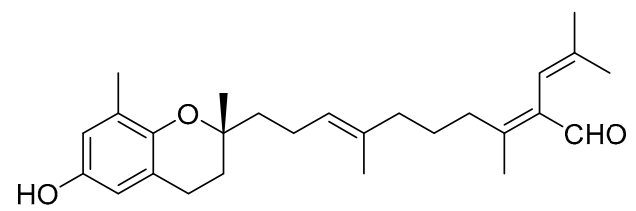

118<smiles>CC(C)=CC(CO)=C(C)CCCC(C)=CCCC1(C)CCc2cc(O)cc(C)c2O1</smiles>

119<smiles>C=C1C(C)=C[C@H](C/C(C)=C/CC[C@]2(C)CCc3cc(O)cc(C)c3O2)[C@H]1C=C(C)C</smiles>

120<smiles>CC(C)=CCCC(=CCCC(C)=CCCC1(C)Oc2c(C)cc(O)cc2CC1O)C(=O)O</smiles>

121<smiles>CC(C)=CCC/C(=C\CC/C(C)=C/CCC(C)(O)C1Cc2cc(O)cc(C)c2O1)C(=O)O</smiles>

122<smiles>CC(C)=CCC/C(C)=C/CC/C(C)=C/CCC1(C)CCc2cc(O)cc(C)c2O1</smiles>

123<smiles>C/C(=C\CC[C@]1(C)CCc2cc(O)cc(C)c2O1)CC/C=C(\C)CCC1OC1(C)C</smiles>

124

Figure 11. Cont. 
<smiles>CC(C)=CCC/C(=C/CC/C(C)=C/CCC1(C)C=Cc2cc(O)cc(C)c2O1)C(=O)O</smiles><smiles>CC(C)=CCC/C(C)=C/[C@H](O)[C@H](O)/C(C)=C/CC[C@]1(C)CCc2cc(O)cc(C)c2O1</smiles>

126<smiles>CC=C(CCC=C(CCC=C(C)C)C(=O)O)CCC[C@]1(C)C=Cc2cc(O)cc(C)c2O1</smiles>

127

Figure 11. Chromenes from Sargassum sp.

Table 3. Chromenes from Sargassum sp.

\begin{tabular}{ccc}
\hline Species & Compounds & Biological Activity \\
\hline S. paradoxum [58] & $\mathbf{9 8}$ & - \\
\hline S. serratifolium $[60]$ & $\mathbf{9 9}$ & - \\
\hline $\begin{array}{c}\text { S. siliquastrum Yoon } \\
{[70-73,77]}\end{array}$ & $\mathbf{1 0 0 - 1 2 0 , 1 2 7}$ & $\begin{array}{c}\text { Anti-inflammatory, antioxidant, radical-scavenging } \\
\text { activity, inhibition of butylcholine esterase }\end{array}$ \\
\hline S. sagamianum $[64,65]$ & $\mathbf{1 2 5}$ & Proapoptotic activity, anticholinesterase activity \\
\hline S. thunbergii $[62]$ & $\mathbf{1 2 1 , 1 2 2 , 1 2 5}$ & Radical scavenging \\
\hline S. tortile $[74-76]$ & $\mathbf{1 2 3 , 1 2 4 , 1 2 6}$ & Larval attractants \\
\hline
\end{tabular}

From S. paradoxum [58], 98 was isolated and from S. serratifolium [60], 99 was isolated. This compound was obtained from sargaquinoic acid 68 upon standing in methanol; it is therefore suggested to be an artifact.

From S. sagamianum, the isolation of $\mathbf{1 2 5}$ and its proapoptotic activity is described [65]. Its anticholinesterase activity and potential use in Alzheimer's disease is also described [64].

From S. siliquastrum, Yoon [70] reported the isolation of $\mathbf{1 0 0}$, and its potential as a novel anti-inflammatory agent was investigated. Lee [71] reported the isolation of 101-106. The antioxidant activity of these compounds was evaluated by various antioxidant tests, such as scavenging effects on generation of intracellular ROS (reactive oxygen species), increments of GSH (glutathione) level, and inhibitory effects on lipid peroxidation in human fibrosarcoma HT 1080 cells. Compounds 101-106 significantly decreased generation of intracellular ROS and inhibited lipid peroxidation while they increased levels of intracellular GSH at a concentration of $5 \mu \mathrm{g} / \mathrm{mL}$. Compound 101 was also isolated by Heo [72] and its anti-inflammatory activity against lipopolysaccharide-exposed RAW 264.7 cells was evaluated. Jang [73] reported the isolation of 101 and 102, together with 107-120. Although the configurations of 101, 102, and 120 are relative, for 109-115 the absolute configurations of the hydroxyl groups were determined by a Mosher's method. Using DPPA (1,1-diphenyl-2-picrylhydrazyl), all of the compounds exhibited significant radical-scavenging activity in the range of $87-91 \%$ at the concentration of $100 \mu \mathrm{g} / \mathrm{mL}$. In addition, compounds 111 and 117 displayed 82.7 and 80.0\% inhibition, 
respectively, toward butylcholine esterase at the same concentration, while the other sargachromanols showed weaker or negligible activity. Cho reported the isolation of $\mathbf{1 2 7}$ and its antioxidant activity [77].

From S. thunbergii [62], 125, 121, and $\mathbf{1 2 2}$ were isolated. They were evaluated as to their capacity to scavenge DPPH radicals, and they exhibited $\mathrm{EC}_{50}$ values of 30 and $31 \mu \mathrm{g} / \mathrm{mL}$, respectively, compared with BHT (butylated hydroxytoluene) $\left(\mathrm{EC}_{50}, 32 \mu \mathrm{g} / \mathrm{mL}\right)$ and $\alpha$-tocopherol $\left(\mathrm{EC}_{50}, 18 \mu \mathrm{g} / \mathrm{mL}\right)$. On their scavenging activity on authentic $\mathrm{ONOO}^{-} /$induced $\mathrm{ONOO}^{-}$from morpholinosydnonimine (SIN-1), their scavenging ratios on authentic $\mathrm{ONOO}^{-}$were 60.0 and $57.1 \%$ at $5 \mu \mathrm{g} / \mathrm{mL}$, respectively, while their inhibition ratios against the generation of $\mathrm{ONOO}^{-}$from SIN-1 were 98.6 and $90.6 \%$ at the same concentration, respectively. Scavenging activities of L-ascorbic acid and penicillamine, positive controls, on authentic/induced $\mathrm{ONOO}^{-}$were 98.1 and $90.4 \%$, and 93.5 and $88.2 \%$, respectively.

From S. tortile, Kato [74] reported the isolation of $\mathbf{1 2 3}$ and 124, together with their activity as attractants of the swimming larvae of Coryne uchidai. Kikuchi $[75,76]$ reported the isolation and identification of 126. Absolute configurations were determined by ECD (electronic circular dichroism).

\subsection{Other Compounds}

Within the constitution of Sargassum sp. we can also find various compounds [48,54,56,61,78-82]. Their structures are in Figure 12 and occurrences are in Table 4.

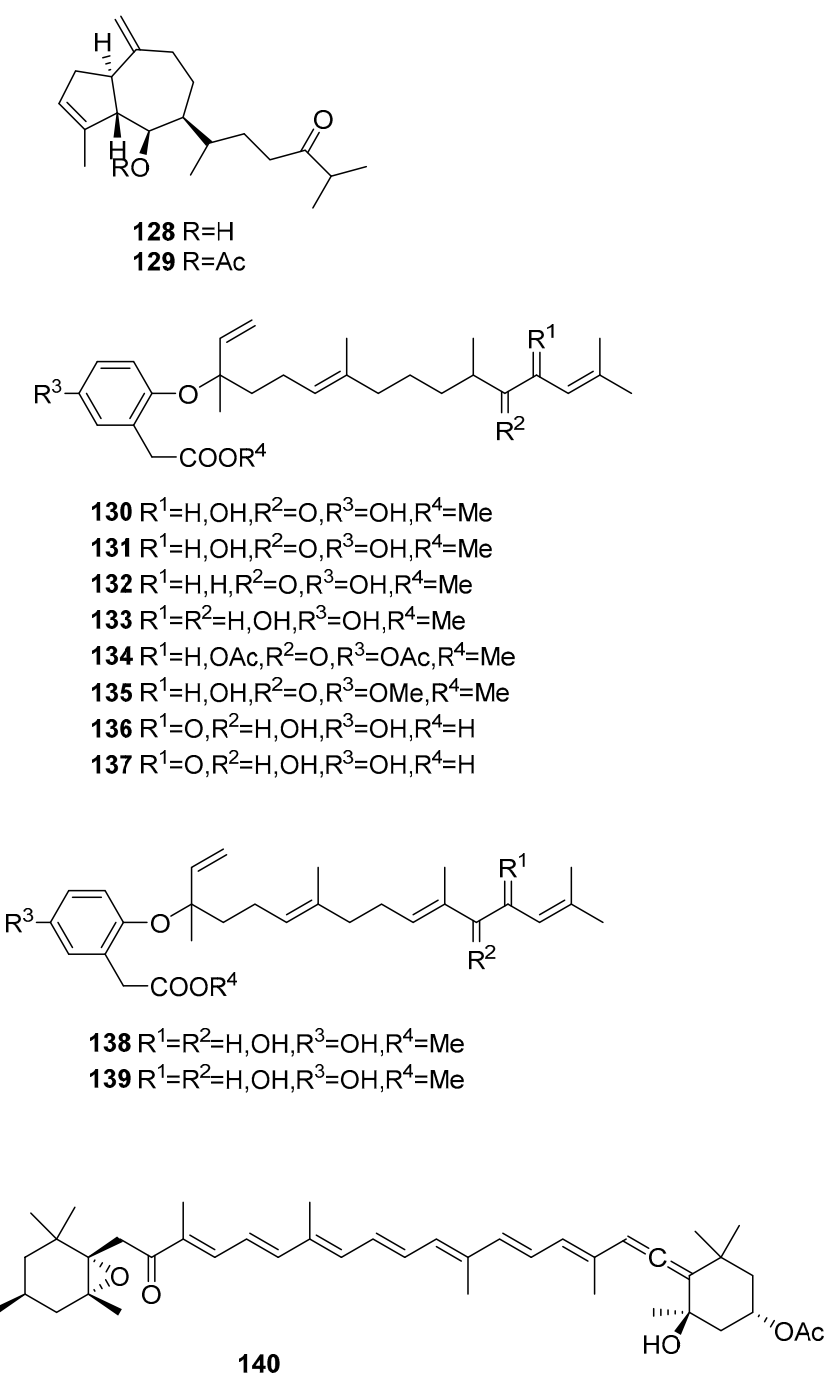

Figure 12. Cont. 
<smiles>COC(=O)C1(C(=O)OC)C=C(C(C)=O)NC1=O</smiles>

141<smiles>COC1=CC(=O)[C@](O)(C(C)=O)C1</smiles>

142<smiles>C=CC(C)(CCC=C(C)C)Oc1ccc(O)cc1CC(C)=O</smiles><smiles>[R1]C(C=C(C)C)C(=O)C(C)CCCC</smiles>

$143 \mathrm{R}^{1}=\mathrm{OH}, \mathrm{R}^{2}=\mathrm{H}$

$144 \mathrm{R}^{1}=\mathrm{H}, \mathrm{R}^{2}=\mathrm{OH}$<smiles>[R]C([R])[C@H](O)/C(C)=C/CCCCC</smiles>

$145 \mathrm{R}^{1}=\mathrm{OH}, \mathrm{R}^{2}=\mathrm{H}$

$146 \mathrm{R}^{1}=\mathrm{H}, \mathrm{R}^{2}=\mathrm{OH}$<smiles>CCCCC(C)[C@@H](O)C(=O)C=C(C)C</smiles>

147<smiles>CCCCC(C)C(O)C(=O)C=C(C)C</smiles>

148<smiles>CCCC=C(C)C(=O)[C@@H](O)C=C(C)C</smiles>

149<smiles>CCCC=C(C)[C@@H](O)C(=O)C=C(C)C</smiles>

$15010^{\prime} E$

$15110^{\prime} Z$<smiles>C=C(C)/C=C/C(O)C(C)CCCC</smiles>

152

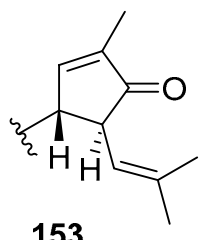

Figure 12. Cont. 
<smiles>[R]Cc1cc(O)cc(CC(=O)OC)c1O</smiles><smiles>CC=C(C)CCC=C(C)CCC=C(C)[C@@H](O)[C@H](O)C=C(C)C</smiles>

$1542^{\prime} Z$

1552 'E<smiles>CC=C(C)CCC=C(C)CCC=C(C)C(=O)C(O)C=C(C)C</smiles>

$1562 ' Z$

$1572^{\prime} E$<smiles>CC=C(C)CCC=C(C)CCCC(C)C(=O)[C@H](O)C=C(C)C</smiles>

$1582^{\prime} E$<smiles>CC=C(C)CCC(=O)C(C)CCC=C(C)C[C@@H](O)C=C(C)C</smiles>

159<smiles>[R6]Oc1cc(O)c(C(=O)CC(C)C)cc1C(C)=O</smiles>

$160 \mathrm{R}=\mathrm{H}$

$161 \mathrm{R}=\mathrm{Me}$

Figure 12. Other structures from Sargassum sp.

Table 4. Other structures from Sargassum sp.

\begin{tabular}{ccc}
\hline Species & Compounds & Biological Activity \\
\hline S. asperifolium [48] & $\mathbf{1 2 8 , 1 2 9}$ & - \\
S. autumnale [78] & $\mathbf{1 3 0 - 1 3 9}$ & Endothelin antagonists \\
S. elegans [54] & $\mathbf{1 4 0}$ & Antioxidant \\
S. fusiformis [79] & $\mathbf{1 4 0}$ & - \\
S. heterophyllum [56] & $\mathbf{1 4 0}$ & Antiplasmodial, cytotoxicity \\
S. Kjellmanium [80,81] & $\mathbf{1 4 1 , 1 4 2}$ & - \\
S. siliquastrum [61] & $\mathbf{1 4 3 - 1 5 9}$ & Radical scaveging, active against isocitrate lyase \\
S. thunbergii [82] & $\mathbf{1 6 0 , 1 6 1}$ & - \\
\hline
\end{tabular}


From S. asperifolium [48], two hydroazulenoids, 128 and 129, were isolated.

From S. autumnale [78], compounds $\mathbf{1 3 0 - 1 3 9}$ were isolated and were tested as endothelin antagonists; they were not always potent and selective.

From S. fusiformis [79], fucoxanthine $\mathbf{1 4 0}$ was isolated by microwave-assisted extraction coupled with high-speed countercurrent chromatography. This compound was also isolated from S. elegans [54] and S. heterophyllum [56]. The antioxidant potential of $\mathbf{1 4 0}$ was evaluated [54] and it also showed a moderate antiplasmodial activity $\left(\mathrm{IC}_{50}=1.5 \mu \mathrm{m}\right)$ [56]. In order to assess the selectivity of fucoxanthin $\mathbf{1 4 0}$ for P. falciparum, the toxicity against a Chinese hamster ovarian cell line was evaluated. The relatively low cytotoxicity of fucoxanthin $\left(\mathrm{IC}_{50}=83.7 \mu \mathrm{m}\right)$ translated into a promising selectivity index (SI = antiplasmodial $\mathrm{IC}_{50} /$ cytotoxicity $\mathrm{IC}_{50}$ ) of 54 [56]. From S. Kjellmanium, 141 [80] and 142 [81] were isolated. For both compounds, the structure was confirmed by single-crystal X-ray analysis.

From S. siliquastrum [61], compounds 143-159 were isolated. They showed moderate to significant radical-scavenging activity in DPPH assays. The 100-fold increase in radical-scavenging activity of the diphenolic isonahocols relative to the monophenolic nahocols indicated the role of the phenolic group in this activity. None of these compounds exhibited antimicrobial activity against Gram-positive or -negative bacteria or against pathogenic fungi. Conversely, the isonahocols 154-159 showed slight activity against sortase A derived from Staphylococcus aureus. The nahocols 143-153 showed no inhibitory activity against sortase A. These compounds were, however, weakly active against isocitrate lyase derived from Candida albicans.

From S. thunbergii [82], two resorcinols were isolated, 160 and 161.

Finally, we can also find reports on the antifouling activity of fats and phthalic acid derivatives from S. confusum [83] and the isolation of farnesylacetones from S.micracanthum [84,85], from S. sagamianum with moderate anticholinesterase activity [86], and from S. siliquastrum with a moderate vasodilatation effect on the basilar arteries of rabbits [87]. Three linear bisnorditerpenes were also isolated from unidentified Sargassum sp. [88].

\section{Biological Activity of Extracts}

Macroalgae continue to attract the attention of researchers, as several reports on the activity of extracts in the literature testify. From the chosen genera here mentioned the following reports can be found.

\subsection{Asparagopsis sp.}

On the bioactivity of extracts from Asparagopsis sp. we can find reports on marine and biomedical antibacterial and antifungal activities of in both species of this genus [89-97]; nematicidal activity of A. taxiformis against the larvae of Meloidogyne javanica [98]; antifouling, anticyanobacterial, piscicidal, and crustacean toxicity of A.taxiformis [99]; and antioxidant and cytotoxic activities of A. armata [100].

\subsection{Caulerpasp.}

For Caulerpa sp., studies on the bioactivity of extracts include antimicrobial activity of C. occidentalis [101], C. cupressoides [102], and Caulerpa sp. [103]; nematicidal activity of C. racemosa against the larvae of Meloidogyne javanica [98]; antioxidant activity of C. lentilifera and C. racemosa [104]; antinociceptive activity of C. racemosa [105], C. mexicana, and C. sertularioides [106]; anti-inflammatory activity of C.mexicana and C. sertularioides [106] and C. peltata [107]; antileishmania of C. cupressoides [102]; and antiviral activity against Dengue of C. racemosa [108] and HSV-1 (herpes simplex virus 1) of C. cupressoides [102]. Aqueous and methanolic extracts of C. mexicana were also found to suppress cell migration and ear edema induced by inflammatory agents [109].

\subsection{Sargassum $s p$.}

Reports on the bioactivity of extracts of Sargassum sp. include antifouling activity of S. muticum [110]; anticoagulant [111], antioxidant [112], and anti-inflammatory [113] activity of S. horneri; antioxidant 
activity of S. siliquastrum [114,115], S. polycystum [116], and Sargassum sp. [117]; antioxidant and anti-cholinesterase activity of $S$. wightii [118]; inhibitory effect on lipid peroxidation of S. micracanthum [119]; antimicrobial activity of S. siliquastrum [120]; antipyretic, analgesic, and anti-inflammatory S. fulvellum and S. thunbergii [121]; anti-inflammatory activity of S. Serratifolium [122]; antiallergenic activity of S. tennerimum [123]; anti-diabetic and hypolipidemic activity of S. yezoense [124]; larvicidal activity against malaria vector Anopheles stephensi of S. swartzii [125]; antigenotoxic activity of S. dentifolium [126]; antitumour activity of S. wightii against Dalton's ascites lymphoma [127] and of S. tenerrimum against Ehrlich ascites carcinoma [128]; and antimelanogenesis activity of S. polycystum [129]. The action of S. fulvellum on skin dermatitis [130] and on neuronal maturation and synaptogenesis [131] is also documented, as well as the chemical genetic effects of S. wightii during embryonic development in zebrafish [132].

\section{Conclusions}

It is interesting to find the differences between the chemical compositions of all three genera. Asparagopsis is mainly rich in halogenated compounds, Caulerpa shows metabolites from varied biosynthetic routes, and Sargassum is rich in meroterpenoids. While biological activity of Asparagopsis metabolites is scarce, Caulerpa metabolites were shown to have inhibitory activity of PTPs, and to be neuroprotective, deterrents, and antibacterial. Sargassum metabolites are cytotoxic to cancer cells, and are antiplasmodial and antioxidants. Of course, only the more recent literature mentions biological activity results for the isolated metabolites. Extracts from all three genera show varied biological activities that make this a promising area of research. There is, however, a need to reinvestigate these genera as particular invasive species in their new host habitat since almost no reports are found on their chemistry. Their success in new environments can surely be correlated to their secondary metabolism and could provide new uses for otherwise noxious species.

Author Contributions: The manuscript was written through contributions of all authors. All authors have given approval to the final version of the manuscript. All authors contributed equally.

Funding: This research received no external funding.

Acknowledgments: Authors acknowledge the Associated Laboratory for Sustainable Chemistry-Clean Processes and Technologies LAQV, which is financed by national funds from FCT/MEC(UID/QUI/50006/2013) and co-financed by the ERDF under the PT2020 Partnership Agreement (POCI-01-0145-FEDER-007265) for ensuring the conditions and means to carry out this work.

Conflicts of Interest: The authors declare no conflicts of interest.

\section{Abbreviations}

$\begin{array}{ll}\text { 1A9 } & \text { human ovarian cancer } \\ \text { A549 } & \text { human lung carcinoma } \\ \text { A } 325-35 & \text { amyloid-peptide fragment 25-35 } \\ \text { CDC25B } & \text { cell division cycle 25 homolog B } \\ \text { DPPA } & \text { 1,1-diphenyl-2-picrylhydrazyl } \\ \text { DPPH } & \text { 1,1-diphenyl-2-picrylhydrazyl } \\ \text { ECD } & \text { electronic circular dichroism } \\ \text { EC } & \text { Effective concentration } \\ \text { ED } & \text { effective dose } \\ \text { EGCG } & \text { epigallocatechin gallate } \\ \text { GSH } & \text { glutathione } \\ \text { HCT8 } & \text { human ilececal cancer } \\ \text { HIV- } & \text { human immunodeficiency virus } \\ \text { HL60 } & \text { promyelocytic leukemia cells } \\ \text { HOS } & \text { human bone tumor } \\ \text { HSV-1 } & \text { herpes simplex virus 1 }\end{array}$




$\begin{array}{ll}\text { IC } & \text { inhibitory concentration } \\ \text { LAR } & \text { leukocyte antigen-related phosphatase } \\ \text { LXR } & \text { liver X receptor } \\ \text { MCF-7 } & \text { breast adenocarcinoma } \\ \text { MIC } & \text { minimum inhibitory concentration } \\ \text { MRSA } & \text { Methicillin-resistant Staphylococcus aureus } \\ \text { P388 } & \text { mouse lymphocytic leukemia } \\ \text { PC3 } & \text { human prostate cancer } \\ \text { PPARs } & \text { Peroxisome proliferator-activated receptors } \\ \text { PTP1B } & \text { protein tyrosine phosphatase 1B } \\ \text { PTPs } & \text { protein phosphatases } \\ \text { ROS } & \text { reactive oxygen species } \\ \text { SHP-1 } & \text { src homology phosphatase-1 } \\ \text { SHP-2 } & \text { src homology phosphatase-2 } \\ \text { SH-SY5Y } & \text { neuroblastoma cell line } \\ \text { SK13 } & \text { Gram-positive spore-forming bacteria requiring Mn for growth } \\ \text { TCPTP } & \text { T-cell PTP }\end{array}$

\section{References}

1. Otero, M.; Cebrian, E.; Francour, P.; Galil, B.; Savini, D. Monitoring Marine Invasive Species in Mediterranean Marine Protected Areas (MPAS)—A Strategy and Practical Guide for Managers; IUCN Centre for Mediterranean Cooperation: Gland, Switzerland, 2013.

2. Groeneveld, R.A.; Bartelings, H.; Börger, T.; Bosello, F.; Buisman, E.; Delpiazzo, E.; Eboli, F.; Fernandes, J.A.; Hamon, K.G.; Hattam, C.; et al. Economic impacts of marine ecological change: Review and recent contributions of the vectors project on european marine waters. Estuar. Coast. Shelf Sci. 2018, 201, 152-163. [CrossRef]

3. Padilla, D.K.; Williams, S.L. Beyond ballast water: Aquarium and ornamental trades as sources of invasive species in aquatic ecosystems. Front. Ecol. Environ. 2004, 2, 131-138. [CrossRef]

4. Inderjit; Chapman, D.; Ranellet, M.; Kaushik, S. Invasive marine algae: An ecological perspective. Bot. Rev. 2006, 72, 153-178.

5. Schaffelke, B.; Smith, J.E.; Hewitt, C.L. Introduced macroalgae-A growing concern. J. Appl. Phycol. 2006, 18, 529-541. [CrossRef]

6. Schaffelke, B.; Hewitt, C.L. Impacts of introduced seaweeds. Bot. Mar. 2007, 50, 397-417. [CrossRef]

7. Valentine, J.P.; Magierowski, R.H.; Johnson, C.R. Mechanisms of invasion: Establishment, spread and persistence of introduced seaweed populations. Bot. Mar. 2007, 50, 351-360. [CrossRef]

8. Williams, S.L.; Grosholz, E.D. The invasive species challenge in estuarine and coastal environments: Marrying management and science. Estuar. Coasts 2008, 31, 3-20. [CrossRef]

9. Anderson, L.W.J. Control of invasive seaweeds. Bot. Mar. 2007, 50, 418-437. [CrossRef]

10. Milledge, J.J.; Nielsen, B.V.; Bailey, D. High-value products from macroalgae: The potential uses of the invasive brown seaweed, Sargassum muticum. Rev. Environ. Sci. Bio-Technol. 2016, 15, 67-88. [CrossRef]

11. Genovese, G.; Tedone, L.; Hamann, M.T.; Morabito, M. The mediterranean red alga Asparagopsis: A source of compounds against leishmania. Mar. Drugs 2009, 7, 361-366. [CrossRef] [PubMed]

12. Ní Chualáin, F.; Maggs, C.A.; Saunders, G.W.; Guiry, M.D. The invasive genus Asparagopsis (bonnemaisoniaceae, rhodophyta): Molecular systematics, morphology, and ecophysiology of falkenbergia isolates. J. Phycol. 2004, 40, 1112-1126. [CrossRef]

13. Dijoux, L.; Viard, F.; Payri, C. The more we search, the more we find: Discovery of a new lineage and a new species complex in the genus Asparagopsis. PLoS ONE 2014, 9, e103826. [CrossRef] [PubMed]

14. Burreson, B.J.; Moore, R.E.; Roller, P. Haloforms in essential oil of alga Asparagopsis-taxiformis (rhodophyta). Tetrahedron Lett. 1975, 473-476. [CrossRef]

15. Burreson, B.J.; Moore, R.E.; Roller, P.P. Volatile halogen compounds in alga Asparagopsis-taxiformis (rhodophyta). J. Agric. Food Chem. 1976, 24, 856-861. [CrossRef] 
16. Woolard, F.X.; Moore, R.E.; Roller, P.P. Halogenated acetamides, but-3-en-2-ols, and isopropanols from Asparagopsis taxiformis (delile) trev. Tetrahedron 1976, 32, 2843-2846. [CrossRef]

17. McConnell, O.; Fenical, W. Halogen chemistry of red alga Asparagopsis. Phytochemistry 1977, 16, $367-374$. [CrossRef]

18. Combaut, G.; Bruneau, Y.; Teste, J.; Codomier, L. Halogen compounds from a red alga, Falkenbergia-rufolanosa, tetrasporophyte of Asparagopsis armata. Phytochemistry 1978, 17, 1661-1663. [CrossRef]

19. Woolard, F.X.; Moore, R.E.; Roller, P.P. Halogenated acetic and acrylic acids from the red alga Asparagopsis taxiformis. Phytochemistry 1979, 18, 617-620. [CrossRef]

20. Abrahamsson, K.; Ekdahl, A.; Collen, J.; Pedersen, M. Marine algae-A source of trichloroethylene and perchloroethylene. Limnol. Oceanogr. 1995, 40, 1321-1326. [CrossRef]

21. Marshall, R.A.; Harper, D.B.; McRoberts, W.C.; Dring, M.J. Volatile bromocarbons produced by falkenbergia stages of Asparagopsis spp. (rhodophyta). Limnol. Oceanogr. 1999, 44, 1348-1352. [CrossRef]

22. Combaut, G.; Bruneau, Y.; Codomier, L.; Teste, J. Comparative sterols composition of the red alga Asparagopsis armata and its tetrasporophyte Falkenbergia rufolanosa. J. Nat. Prod. 1979, 42, 150-151. [CrossRef] [PubMed]

23. Lopes, G.; Sousa, C.; Bernardo, J.; Andrade, P.B.; Valentao, P.; Ferreres, F.; Mouga, T. Sterol profiles in 18 macroalgae of the portuguese coast. J. Phycol. 2011, 47, 1210-1218. [CrossRef] [PubMed]

24. Francisco, C.; Combaut, G.; Teste, J.; Tarchini, C.; Djerassi, C. Side chain-hydroxylated sterols of the red alga Asparagopsis armata-Significant products or artifacts due to autoxidation. Steroids 1979, 34, 163-169. [CrossRef]

25. Greff, S.; Zubia, M.; Genta-Jouve, G.; Massi, L.; Perez, T.; Thomas, O.P. Mahorones, highly brominated cyclopentenones from the red alga Asparagopsis taxiformis. J. Nat. Prod. 2014, 77, 1150-1155. [CrossRef] [PubMed]

26. Žuljević, A.; Thibaut, T.; Despalatović, M.; Cottalorda, J.-M.; Nikolić, V.; Cvitković, I.; Antolić, B. Invasive alga Caulerpa racemosa var. Cylindracea makes a strong impact on the mediterranean sponge sarcotragus spinosulus. Biol. Invasions 2011, 13, 2303-2308. [CrossRef]

27. Kersting, D.K.; Ballesteros, E.; De Caralt, S.; Linares, C. Invasive macrophytes in a marine reserve (columbretes islands, nw mediterranean): Spread dynamics and interactions with the endemic scleractinian coral cladocora caespitosa. Biol. Invasions 2014, 16, 1599-1610. [CrossRef]

28. Klein, J.; Verlaque, M. The Caulerpa racemosa invasion: A critical review. Mar. Pollut. Bull. 2008, 56, $205-225$. [CrossRef] [PubMed]

29. Denapoli, L.; Fattorusso, E.; Magno, S.; Mayol, L. 3 squalene derivatives from Caulerpa prolifera. Phytochemistry 1982, 21, 782-784. [CrossRef]

30. Aliya, R.; Shameel, M. Marine natural products of Caulerpa (siphonocladophyceae). Pak. J. Bot. 2003, 35, 659-669.

31. Yang, P.; Liu, D.Q.; Liang, T.J.; Li, J.; Zhang, H.Y.; Liu, A.H.; Guo, Y.W.; Mao, S.C. Bioactive constituents from the green alga Caulerpa racemosa. Bioorg. Med. Chem. 2015, 23, 38-45. [CrossRef] [PubMed]

32. Liu, A.-H.; Liu, D.-Q.; Liang, T.-J.; Yu, X.-Q.; Feng, M.-T.; Yao, L.-G.; Fang, Y.; Wang, B.; Feng, L.-H.; Zhang, M.-X.; et al. Caulerprenylols a and $b$, two rare antifungal prenylated para-xylenes from the green alga Caulerpa racemosa. Bioorg. Med. Chem. Lett. 2013, 23, 2491-2494. [CrossRef] [PubMed]

33. Liu, D.-Q.; Mao, S.-C.; Zhang, H.-Y.; Yu, X.-Q.; Feng, M.-T.; Wang, B.; Feng, L.-H.; Guo, Y.-W. Racemosins $\mathrm{a}$ and $\mathrm{b}$, two novel bisindole alkaloids from the green alga Caulerpa racemosa. Fitoterapia 2013, 91, 15-20. [CrossRef] [PubMed]

34. Aguilar-Santos, G. Caulerpin, a new red pigment from green algae of genus Caulerpa. J. Chem. Soc. C Org. 1970, 6, 842-843. [CrossRef]

35. Capon, R.J.; Ghisalberti, E.L.; Jefferies, P.R. New sesquiterpenes from Caulerpa flexilis var. Muelleri. Aust. J. Chem. 1981, 34, 1775-1778. [CrossRef]

36. Guerriero, A.; Meinesz, A.; D'Ambrosio, M.; Pietra, F. Isolation of toxic and potentially toxic sesqui- and monoterpenes from the tropical green seaweed Caulerpa taxifolia which has invaded the region of cap martin and monaco. Helv. Chim. Acta 1992, 75, 689-695. [CrossRef]

37. Amico, V.; Oriente, G.; Piattelli, M.; Trinyali, C.; Fattorusso, E.; Mayno, S.; Mayo, L. Caulerpenyne, an unusual sequiterpenoid from the green alga Caulerpa prolifera. Tetrahedron Lett. 1978, 38, 3593-3596. [CrossRef] 
38. Paul, V.J.; Fenlcal, W. Toxic feeding deterrents from the tropical marine alga cavlerpa bikinensis (chlorophyta). Tetrahedron Lett. 1982, 23, 5017-5020. [CrossRef]

39. Paul, V.J.; Littler, M.M.; Littler, D.S.; Fenical, W. Evidence for chemical defense in tropical green alga Caulerpa ashmeadii (caulerpaceae: Chlorophyta): Isolation of new bioactive sesquiterpenoids. J. Chem. Ecol. 1987, 13, 1171-1185. [CrossRef] [PubMed]

40. Capon, R.J.; Ghisalberti, E.L.; Jefferies, P.R. Metabolites of the green algae, caulerpa species. Phytochemistry 1983, 22, 1465-1467. [CrossRef]

41. Paul, V.J.; Fenical, W. Diterpenoid metabolites from pacific marine algae of the order caulerpales (chlorophyta). Phytochemistry 1985, 24, 2239-2243. [CrossRef]

42. Handley, J.T.; Blackman, A.J. Secondary metabolites from the marine alga Caulerpa brownii (chlorophyta). Aust. J. Chem. 2005, 58, 39-46. [CrossRef]

43. Knoepfflerpeguy, M.; Belsher, T.; Boudouresque, C.F.; Lauret, M. Sargassum-muticum begins to invade the mediterranean. Aquat. Bot. 1985, 23, 291-295. [CrossRef]

44. Boudouresque, C.F.; Verlaque, M. Biological pollution in the mediterranean sea: Invasive versus introduced macrophytes. Mar. Pollut. Bull. 2002, 44, 32-38. [CrossRef]

45. Critchley, A.T. Sargassum-muticum-A taxonomic history including world-wide and western pacific distributions. J. Mar. Biol. Assoc. U. K. 1983, 63, 617-625. [CrossRef]

46. Critchley, A.T.; Dijkema, R. On the presence of the introduced brown alga Sargassum muticum, attached to commercially imported ostrea-edulis in the sw netherlands. Bot. Mar. 1984, 27, 211-216. [CrossRef]

47. Yende, S.R.; Harle, U.N.; Chaugule, B.B. Therapeutic potential and health benefits of sargassum species. Pharmacogn. Rev. 2014, 8, 1-7. [CrossRef] [PubMed]

48. Ayyad, S.-E.N.; Sowellim, S.Z.A.; El-Hosini, M.S.; Abo-Atia, A. The structural determination of a new steroidal metabolite from the brown alga Sargassum asperifolium. Z. Naturforsch. Sect. C J. Biosci. 2003, 58c, 333-336.

49. Tang, H.F.; Yi, Y.H.; Yao, X.S.; Xu, Q.Z.; Zhang, S.Y.; Lin, H.W. Bioactive steroids from the brown alga Sargassum carpophyllum. J. Asian Nat. Prod. Res. 2002, 4, 95-101. [CrossRef] [PubMed]

50. Zhen, X.-H.; Quan, Y.-C.; Jiang, H.-Y.; Wen, Z.-S.; Qu, Y.-L.; Guan, L.-P. Fucosterol, a sterol extracted from Sargassum fusiforme, shows antidepressant and anticonvulsant effects. Eur. J. Pharmacol. 2015, 768, 131-138. [CrossRef] [PubMed]

51. Chen, Z.; Liu, J.; Fu, Z.; Ye, C.; Zhang, R.; Song, Y.; Zhang, Y.; Li, H.; Ying, H.; Liu, H. 24(s)-saringosterol from edible marine seaweed Sargassum fusiforme is a novel selective lxr beta agonist. J. Agric. Food Chem. 2014, 62, 6130-6137. [CrossRef] [PubMed]

52. Permeh, P.; Saeidnia, S.; Mashinchian-Moradi, A.; Gohari, A.R. Sterols from Sargassum oligocystum, a brown algae from the persian gulf, and their bioactivity. Nat. Prod. Res. 2012, 26, 774-777. [CrossRef] [PubMed]

53. He, W.-F.; Yao, L.-G.; Liu, H.-L.; Guo, Y.-W. Thunberol, a new sterol from the chinese brown alga Sargassum thunbergii. J. Asian Nat. Prod. Res. 2014, 16, 685-689. [CrossRef] [PubMed]

54. Ragubeer, N.; Limson, J.L.; Beukes, D.R. Electrochemistry-guided isolation of antioxidant metabolites from Sargassum elegans. Food Chem. 2012, 131, 286-290. [CrossRef]

55. Reddy, P.; Urban, S. Meroditerpenoids from the southern australian marine brown alga Sargassum fallax. Phytochemistry 2009, 70, 250-255. [CrossRef] [PubMed]

56. Afolayan, A.F.; Bolton, J.J.; Lategan, C.A.; Smith, P.J.; Beukes, D.R. Fucoxanthin, tetraprenylated toluquinone and toluhydroquinone metabolites from Sargassum heterophyllum inhibit the in vitro growth of the malaria parasite plasmodium falciparum. Z. Naturforsch. Sect. C J. Biosci. 2008, 63, 848-852. [CrossRef]

57. Mori, J.; Iwashima, M.; Wakasugi, H.; Saito, H.; Matsunaga, T.; Ogasawara, M.; Takahashi, S.; Suzuki, H.; Hayashi, T. New plastoquinones isolated from the brown alga, Sargassum micracanthum. Chem. Pharm. Bull. 2005, 53, 1159-1163. [CrossRef] [PubMed]

58. Brkljaca, R.; Urban, S. Chemical profiling (hplc-nmr \& hplc-ms), isolation, and identification of bioactive meroditerpenoids from the southern australian marine brown alga Sargassum paradoxum. Mar. Drugs 2015, 13, 102-127. [CrossRef]

59. Segawa, M.; Shirahama, H. New plastoquinones from the brown alga Sargassum sagamianum var yezoense. Chem. Lett. 1987, 1365-1366. [CrossRef]

60. Kusumi, T.; Shibata, Y.; Ishitsuka, M.; Kinoshita, T.; Kakisawa, H. Structures of new plastoquinones from the brown alga Sargassum serratifolium. Chem. Lett. 1979, 277-278. [CrossRef] 
61. Jung, M.; Jang, K.H.; Kim, B.; Lee, B.H.; Choi, B.W.; Oh, K.-B.; Shin, J. Meroditerpenoids from the brown alga Sargassum siliquastrum. J. Nat. Prod. 2008, 71, 1714-1719. [CrossRef] [PubMed]

62. Seo, Y.; Park, K.E.; Kim, Y.A.; Lee, H.-J.; Yoo, J.-S.; Ahn, J.-W.; Lee, B.-J. Isolation of tetraprenyltoluquinols from the brown alga Sargassum thunbergii. Chem. Pharm. Bull. 2006, 54, 1730-1733. [CrossRef] [PubMed]

63. Kim, J.-A.; Karadeniz, F.; Ahn, B.-N.; Kwon, M.S.; Mun, O.-J.; Bae, M.J.; Seo, Y.; Kim, M.; Lee, S.-H.; Kim, Y.Y.; et al. Bioactive quinone derivatives from the marine brown alga Sargassum thunbergii induce anti-adipogenic and pro-osteoblastogenic activities. J. Sci. Food Agric. 2016, 96, 783-790. [CrossRef] [PubMed]

64. Choi, B.W.; Ryu, G.; Park, S.H.; Kim, E.S.; Shin, J.; Roh, S.S.; Shin, H.C.; Lee, B.H. Anticholinesterase activity of plastoquinones from Sargassum sagamianum: Lead compounds for alzheimer's disease therapy. Phytother. Res. 2007, 21, 423-426. [CrossRef] [PubMed]

65. Hur, S.; Lee, H.; Kim, Y.; Lee, B.-H.; Shin, J.; Kim, T.-Y. Sargaquinoic acid and sargachromenol, extracts of Sargassum sagamianum, induce apoptosis in hacat cells and mice skin: Its potentiation of uvb-induced apoptosis. Eur. J. Pharmacol. 2008, 582, 1-11. [CrossRef] [PubMed]

66. Ishitsuka, M.; Kusumi, T.; Nomura, Y.; Konno, T.; Kakisawa, H. New geranylgeranylbenzoquinone derivatives from Sargassum tortile. Chem. Lett. 1979, 1269-1272. [CrossRef]

67. Kim, S.-N.; Choi, H.Y.; Lee, W.; Park, G.M.; Shin, W.S.; Kim, Y.K. Sargaquinoic acid and sargahydroquinoic acid from Sargassum yezoense stimulate adipocyte differentiation through ppar alpha/gamma activation in 3t3-11 cells. FEBS Lett. 2008, 582, 3465-3472. [CrossRef] [PubMed]

68. Kim, M.C.; Kwon, H.C.; Kim, S.N.; Kim, H.S.; Um, B.H. Plastoquinones from Sargassum yezoense; chemical structures and effects on the activation of peroxisome proliferator-activated receptor gamma. Chem. Pharm. Bull. 2011, 59, 834-838. [CrossRef] [PubMed]

69. Kang, G.-J.; Han, S.-C.; Yoon, W.-J.; Koh, Y.-S.; Hyun, J.-W.; Kang, H.-K.; Cho, J.Y.; Yoo, E.-S. Sargaquinoic acid isolated from Sargassum siliquastrum inhibits lipopolysaccharide-induced nitric oxide production in macrophages via modulation of nuclear factor-kappa b and c-jun n-terminal kinase pathways. Immunopharmacol. Immunotoxicol. 2012, 35, 80-87. [CrossRef] [PubMed]

70. Yoon, W.-J.; Heo, S.-J.; Han, S.-C.; Lee, H.-J.; Kang, G.-J.; Kang, H.-K.; Hyun, J.-W.; Koh, Y.-S.; Yoo, E.-S. Anti-inflammatory effect of sargachromanol $\mathrm{g}$ isolated from Sargassum siliquastrum in raw 264.7 cells. Arch. Pharm. Res. 2012, 35, 1421-1430. [CrossRef] [PubMed]

71. Lee, J.I.; Seo, Y. Chromanols from Sargassum siliquastrum and their antioxidant activity in ht 1080 cells. Chem. Pharm. Bull. 2011, 59, 757-761. [CrossRef] [PubMed]

72. Heo, S.-J.; Jang, J.; Ye, B.-R.; Kim, M.-S.; Yoon, W.-J.; Oh, C.; Kang, D.-H.; Lee, J.-H.; Kang, M.-C.; Jeon, Y.-J.; et al. Chromene suppresses the activation of inflammatory mediators in lipopolysaccharide-stimulated raw 264.7 cells. Food Chem. Toxicol. 2014, 67, 169-175. [CrossRef] [PubMed]

73. Jang, K.H.; Lee, B.H.; Choi, B.W.; Lee, H.S.; Shin, J. Chromenes from the brown alga Sargassum siliquastrum. J. Nat. Prod. 2005, 68, 716-723. [CrossRef] [PubMed]

74. Kato, T.; Kumanireng, A.S.; Ichinose, I.; Kitahara, Y.; Kakinuma, Y.; Nishihira, M.; Kato, M. Active components of Sargassum tortile effecting settlement of swimming larvae of coryne-uchidai. Experientia 1975, 31, 433-434. [CrossRef] [PubMed]

75. Kikuchi, T.; Mori, Y.; Yokoi, T.; Nakazawa, S.; Kuroda, H.; Masada, Y.; Kitamura, K.; Kuriyama, K. Structure and absolute-configuration of sargatriol, a new isoprenoid chromenol from a brown alga, Sargassum tortile C. AGARDH. Chem. Pharm. Bull. 1983, 31, 106-113. [CrossRef]

76. Kikuchi, T.; Mori, Y.; Yokoi, T.; Nakazawa, S.; Kuroda, H.; Masada, Y.; Kitamura, K.; Umezaki, I. Structure of sargatriol, a new isoprenoid chromenol from a marine alga-Sargassum tortile. Chem. Pharm. Bull. 1975, 23, 690-692. [CrossRef]

77. Cho, S.H.; Cho, J.Y.; Kang, S.E.; Hong, Y.K.; Ahn, D.H. Antioxidant activity of mojabanchromanol, a novel chromene, isolated from brown alga Sargassum siliquastrum. J. Environ. Biol. 2008, 29, 479-484. [PubMed]

78. Tsuchiya, N.; Sato, A.; Haruyama, H.; Watanabe, T.; Iijima, Y. Nahocols and isonahocols, endothelin antagonists from the brown alga, Sargassum autumnale. Phytochemistry 1998, 48, 1003-1011. [CrossRef]

79. Xiao, X.; Si, X.; Yuan, Z.; Xu, X.; Li, G. Isolation of fucoxanthin from edible brown algae by microwave-assisted extraction coupled with high-speed countercurrent chromatography. J. Sep. Sci. 2012, 35, 2313-2317. [CrossRef] [PubMed] 
80. Nozaki, H.; Fukuoka, Y.; Matsuo, A.; Soga, O.; Nakayama, M. Structure of sargassumlactam, a new beta,gamma-unsaturated-gamma-lactam, from the marine alga Sargassum kjellmanianum. Chem. Lett. 1980, 1453-1454. [CrossRef]

81. Nakayama, M.; Fukuoka, Y.; Nozaki, H.; Matsuo, A.; Hayashi, S. Structure of (+)-kjellmanianone, a highly oxygenated cyclopentenone from the marin alga, Sargassum kjellmanianum. Chem. Lett. 1980, 1243-1246. [CrossRef]

82. Cai, Y.-P.; Xie, C.-B.; Wang, B.-C.; Li, P.-L.; Li, B.-F. Two new resorcinols from Sargassum thunbergii. J. Asian Nat. Prod. Res. 2010, 12, 1001-1004. [CrossRef] [PubMed]

83. Ganti, V.S.; Kim, K.H.; Bhattarai, H.D.; Shin, H.W. Isolation and characterisation of some antifouling agents from the brown alga Sargassum confusum. J. Asian Nat. Prod. Res. 2006, 8, 309-315. [CrossRef] [PubMed]

84. Shizuri, Y.; Matsukawa, S.; Ojika, M.; Yamada, K. 2 new farnesylacetone derivatives from the brown alga Sargassum micracanthum. Phytochemistry 1982, 21, 1808-1809. [CrossRef]

85. Kusumi, T.; Ishitsuka, M.; Nomura, Y.; Konno, T.; Kakisawa, H. New farnesylacetone derivatives from Sargassum micracanthum. Chem. Lett. 1979, 8, 1181-1184. [CrossRef]

86. Ryu, G.; Park, S.H.; Kim, E.S.; Choi, B.W.; Ryu, S.Y.; Lee, B.H. Cholinesterase inhibitory activity of two farnesylacetone derivatives from the brown alga Sargassum sagamianum. Arch. Pharm. Res. 2003, 26, 796-799. [CrossRef] [PubMed]

87. Park, B.-G.; Kwon, S.-C.; Park, G.-M.; Ham, J.; Shin, W.-S.; Lee, S. Vasodilatation effect of farnesylacetones, active constituents of Sargassum siliquastrum, on the basilar and carotid arteries of rabbits. Bioorg. Med. Chem. Lett. 2008, 18, 6324-6326. [CrossRef] [PubMed]

88. Takada, N.; Watanabe, R.; Suenaga, K.; Yamada, K.; Uemura, D. Isolation and structures of hedaols a, b, and c, new bisnorditerpenes from a japanese brown alga. J. Nat. Prod. 2001, 64, 653-655. [CrossRef] [PubMed]

89. Salvador, N.; Gomez Garreta, A.; Lavelli, L.; Antonia Ribera, M. Antimicrobial activity of iberian macroalgae. Sci. Mar. 2007, 71, 101-113. [CrossRef]

90. Manilal, A.; Sujith, S.; Kiran, G.S.; Selvin, J.; Shakir, C.; Gandhimathi, R.; Lipton, A.P. Antimicrobial potential and seasonality of red algae collected from the southwest coast of india tested against shrimp, human and phytopathogens. Ann. Microbiol. 2009, 59, 207-219. [CrossRef]

91. Rhimou, B.; Hassane, R.; Nathalie, B. Antiviral activity of the extracts of rhodophyceae from morocco. Afr. J. Biotechnol. 2010, 9, 7968-7975.

92. Pinteus, S.; Alves, C.; Monteiro, H.; Araujo, E.; Horta, A.; Pedrosa, R. Asparagopsis armata and sphaerococcus coronopifolius as a natural source of antimicrobial compounds. World J. Microbiol. Biotechnol. 2015, 31, 445-451. [CrossRef] [PubMed]

93. Vedhagiri, K.; Manilal, A.; Valliyammai, T.; Shanmughapriya, S.; Sujith, S.; Selvin, J.; Natarajaseenivasan, K. Antimicrobial potential of a marine seaweed Asparagopsis taxiformis against leptospira javanica isolates of rodent reservoirs. Ann. Microbiol. 2009, 59, 431-437. [CrossRef]

94. Paul, N.A.; de Nys, R.; Steinberg, P.D. Chemical defence against bacteria in the red alga Asparagopsis armata: Linking structure with function. Mar. Ecol. Prog. Ser. 2006, 306, 87-101. [CrossRef]

95. Genovese, G.; Faggio, C.; Gugliandolo, C.; Torre, A.; Spano, A.; Morabito, M.; Maugeri, T.L. In vitro evaluation of antibacterial activity of Asparagopsis taxiformis from the straits of messina against pathogens relevant in aquaculture. Mar. Environ. Res. 2012, 73, 1-6. [CrossRef] [PubMed]

96. Manilal, A.; Selvin, J.; George, S. In vivo therapeutic potentiality of red seaweed, Asparagopsis (bonnemaisoniales, rhodophyta) in the treatment of vibriosis in penaeus monodon fabricius. Saudi J. Biol. Sci. 2012, 19, 165-175. [CrossRef] [PubMed]

97. Genovese, G.; Leitner, S.; Minicante, S.A.; Lass-Floerl, C. The mediterranean red alga Asparagopsis taxiformis has antifungal activity against aspergillus species. Mycoses 2013, 56, 516-519. [CrossRef] [PubMed]

98. Rizvi, M.A.; Shameel, M. In vitro nematicidal activities of seaweed extracts from karachi coast. Pak. J. Bot. 2006, 38, 1245-1248.

99. Manilal, A.; Sujith, S.; Sabarathnam, B.; Kiran, G.S.; Selvin, J.; Shakir, C.; Lipton, A.P. Bioactivity of the red algae Asparagopsis taxiformis collected from the southwestern coast of india. Braz. J. Oceanogr. 2010, 58, 93-100. [CrossRef]

100. Zubia, M.; Fabre, M.-S.; Kerjean, V.; Deslandes, E. Antioxidant and cytotoxic activities of some red algae (rhodophyta) from Brittany Coasts (France). Bot. Mar. 2009, 52, 268-277. [CrossRef] 
101. Al-Saif, S.; Abdel-Raouf, N.; El-Wazanani, H.A.; Aref, I.A. Antibacterial substances from marine algae isolated from jeddah coast of red sea, saudi arabia. Saudi J. Biol. Sci. 2014, 21, 57-64. [CrossRef] [PubMed]

102. Bianco, E.M.; de Oliveira, S.Q.; Rigotto, C.; Tonini, M.L.; Guimaraes, T.D.; Bittencourt, F.; Gouvea, L.P.; Aresi, C.; de Almeida, M.T.R.; Moritz, M.I.G.; et al. Anti-infective potential of marine invertebrates and seaweeds from the brazilian coast. Molecules 2013, 18, 5761-5778. [CrossRef] [PubMed]

103. Manikandan, S.; Ganesapandian, S.; Singh, M.; Sangeetha, N.; Kumaraguru, A.K. Antimicrobial activity of seaweeds against multi drug resistant strains. Int. J. Pharmacol. 2011, 7, 522-526. [CrossRef]

104. Matanjun, P.; Mohamed, S.; Mustapha, N.M.; Muhammad, K.; Ming, C.H. Antioxidant activities and phenolics content of eight species of seaweeds from north borneo. J. Appl. Phycol. 2008, 20, 367-373. [CrossRef]

105. Souza, E.T.; de Queiroz, A.C.; de Miranda, G.E.C.; Lorenzo, V.R.; da Silva, E.F.; Freire-Dias, T.L.M.; Cupertino-Silva, Y.K.; Melo, G.M.D.; Santos, B.V.O.; Chaves, M.C.D.; et al. Antinociceptive activities of crude methanolic extract and phases, n-butanolic, chloroformic and ethyl acetate from Caulerpa racemosa (caulerpaceae). Rev. Bras. Farmacogn. Braz. J. Pharmacogn. 2009, 19, 115-120. [CrossRef]

106. Da Matta, C.B.B.; de Souza, E.T.; de Queiroz, A.C.; de Lira, D.P.; de Araujo, M.V.; Cavalcante-Silva, L.H.A.; de Miranda, G.E.C.; de Araujo, J.X.; Barbosa, J.M.; Santos, B.V.D.; et al. Antinociceptive and anti-inflammatory activity from algae of the genus caulerpa. Mar. Drugs 2011, 9, 307-318. [CrossRef] [PubMed]

107. Murugan, K.; Iyer, V.V. Antioxidant activity and gas chromatographic-mass spectrometric analysis of extracts of the marine algae, Caulerpa peltata and Padina gymnospora. Indian J. Pharm. Sci. 2014, 76, 548-552. [PubMed]

108. Koishi, A.C.; Zanello, P.R.; Bianco, E.M.; Bordignon, J.; dos Santos, C.N.D. Screening of dengue virus antiviral activity of marine seaweeds by an in situ enzyme-linked immunosorbent assay. PLoS ONE 2012, 7, e51089. [CrossRef] [PubMed]

109. Bitencourt, M.A.O.; Dantas, G.R.; Lira, D.P.; Barbosa, J.M.; de Miranda, G.E.; Santos, B.V.D.; Souto, J.T. Aqueous and methanolic extracts of Caulerpa mexicana suppress cell migration and ear edema induced by inflammatory agents. Mar. Drugs 2011, 9, 1332-1345. [CrossRef] [PubMed]

110. Silkina, A.; Bazes, A.; Mouget, J.-L.; Bourgougnon, N. Comparative efficiency of macroalgal extracts and booster biocides as antifouling agents to control growth of three diatom species. Mar. Pollut. Bull. 2012, 64, 2039-2046. [CrossRef] [PubMed]

111. Athukorala, Y.; Lee, K.-W.; Kim, S.-K.; Jeon, Y.-J. Anticoagulant activity of marine green and brown algae collected from Jeju Island in Korea. Bioresour. Technol. 2007, 98, 1711-1716. [CrossRef] [PubMed]

112. Heo, S.J.; Park, E.J.; Lee, K.W.; Jeon, Y.J. Antioxidant activities of enzymatic extracts from brown seaweeds. Bioresour. Technol. 2005, 96, 1613-1623. [CrossRef] [PubMed]

113. Kim, M.E.; Jung, Y.C.; Jung, I.; Lee, H.-W.; Youn, H.-Y.; Lee, J.S. Anti-inflammatory effects of ethanolic extract from Sargassum horneri (turner) c. Agardh on lipopolysaccharide-simulated macrophage activation via nf-kappa b pathway regulation. Immunol. Investig. 2015, 44, 137-146. [CrossRef] [PubMed]

114. Cho, S.-H.; Kang, S.-E.; Cho, J.-Y.; Kim, A.-R.; Park, S.-M.; Hong, Y.-K.; Ahn, D.-H. The antioxidant properties of brown seaweed (Sargassum siliquastrum) extracts. J. Med. Food 2007, 10, 479-485. [CrossRef] [PubMed]

115. Lim, S.N.; Cheung, P.C.K.; Ooi, V.E.C.; Ang, P.O. Evaluation of antioxidative activity of extracts from a brown seaweed, Sargassum siliquastrum. J. Agric. Food Chem. 2002, 50, 3862-3866. [CrossRef] [PubMed]

116. Raghavendran, H.R.B.; Sathivel, A.; Devaki, T. Antioxidant effect of Sargassum polycystum (phaeophyceae) against acetaminophen induced changes in hepatic mitochondrial enzymes during toxic hepatitis. Chemosphere 2005, 61, 276-281. [CrossRef] [PubMed]

117. Garcia-Casal, M.N.; Ramirez, J.; Leets, I.; Pereira, A.C.; Quiroga, M.F. Antioxidant capacity, polyphenol content and iron bioavailability from algae (Ulva sp., Sargassum sp and Porphyra sp.) in human subjects. Br. J. Nutr. 2009, 101, 79-85. [CrossRef] [PubMed]

118. Syad, A.N.; Shunmugiah, K.P.; Kasi, P.D. Antioxidant and anti-cholinesterase activity of Sargassum wightii. Pharm. Biol. 2013, 51, 1401-1410. [CrossRef] [PubMed]

119. Mori, J.; Matsunaga, T.; Takahashi, S.; Hasegawa, C.; Saito, H. Inhibitory activity on lipid peroxidation of extracts from marine brown alga. Phytother. Res. 2003, 17, 549-551. [CrossRef] [PubMed]

120. Choi, J.-S.; Ha, Y.-M.; Joo, C.-U.; Cho, K.K.; Kim, S.-J.; Choi, I.S. Inhibition of oral pathogens and collagenase activity by seaweed extracts. J. Environ. Biol. 2012, 33, 115-121. [PubMed] 
121. Kang, J.Y.; Khan, M.N.A.; Park, N.H.; Cho, J.Y.; Lee, M.C.; Fujii, H.; Hong, Y.K. Antipyretic, analgesic, and anti-inflammatory activities of the seaweed Sargassum fulvellum and Sargassum thunbergii in mice. J. Ethnopharmacol. 2008, 116, 187-190. [CrossRef] [PubMed]

122. Oh, S.-J.; Joung, E.-J.; Kwon, M.-S.; Lee, B.; Utsuki, T.; Oh, C.-W.; Kim, H.-R. Anti-inflammatory effect of ethanolic extract of Sargassum serratifolium in lipopolysaccharide-stimulated bv2 microglial cells. J. Med. Food 2016, 19, 1023-1031. [CrossRef] [PubMed]

123. Samee, H.; Li, Z.-x.; Lin, H.; Khalid, J.; Guo, Y.-c. Anti-allergic effects of ethanol extracts from brown seaweeds. J. Zhejiang Univ. Sci. B 2009, 10, 147-153. [CrossRef] [PubMed]

124. Kim, S.-N.; Lee, W.; Bae, G.-U.; Kim, Y.K. Anti-diabetic and hypolipidemic effects of Sargassum yezoense in $\mathrm{db} / \mathrm{db}$ mice. Biochem. Biophys. Res. Commun. 2012, 424, 675-680. [CrossRef] [PubMed]

125. Khanavi, M.; Toulabi, P.B.; Abai, M.R.; Sadati, N.; Hadjiakhoondi, F.; Hadjiakhoondi, A.; Vatandoost, H. Larvicidal activity of marine algae, Sargassum swartzii and Chondria dasyphylla, against malaria vector Anopheles stephensi. J. Vector Borne Dis. 2011, 48, 241-244. [PubMed]

126. Gamal-Eldeen, A.M.; Abo-Zeid, M.A.M.; Ahmed, E.F. Anti-genotoxic effect of the Sargassum dentifolium extracts: Prevention of chromosomal aberrations, micronuclei, and DNA fragmentation. Exp. Toxicol. Pathol. 2013, 65, 27-34. [CrossRef] [PubMed]

127. Rajan, D.S.; Rajkumar, M.; Srinivasan, R.; Harikumar, R.P.; Suresh, S.; Kumar, S. Antitumour activity of Sargassum wightii (greville) extracts against dalton's ascites lymphoma. Pak. J. Biol. Sci. PJBS 2013, 16, 1336-1341. [CrossRef] [PubMed]

128. Patra, S.; Muthuraman, M.S.; Prabhu, A.R.; Priyadharshini, R.R.; Parthiban, S. Evaluation of antitumor and antioxidant activity of Sargassum tenerrimum against ehrlich ascites carcinoma in mice. Asian Pac. J. Cancer Prev. APJCP 2015, 16, 915-921. [CrossRef] [PubMed]

129. Chan, Y.Y.; Kim, K.H.; Cheah, S.H. Inhibitory effects of Sargassum polycystum on tyrosinase activity and melanin formation in b16f10 murine melanoma cells. J. Ethnopharmacol. 2011, 137, 1183-1188. [CrossRef] [PubMed]

130. Kang, B.-K.; Kim, M.-J.; Kim, K.-B.-W.-R.; Ahn, D.-H. In vivo and in vitro inhibitory activity of an ethanolic extract of Sargassum fulvellum and its component grasshopper ketone on atopic dermatitis. Int. Immunopharmacol. 2016, 40, 176-183. [CrossRef] [PubMed]

131. Hannan, M.A.; Kang, J.-Y.; Hong, Y.-K.; Lee, H.; Chowdhury, M.T.H.; Choi, J.-S.; Choi, I.S.; Moon, I.S. A brown alga Sargassum fulvellum facilitates neuronal maturation and synaptogenesis In Vitro. Cell. Dev. Biol. Anim. 2012, 48, 535-544. [CrossRef] [PubMed]

132. Kannan, R.R.; Iniyan, A.M.; Vincent, S.G.P. Chemical genetic effects of Sargassum wightii during embryonic development in zebrafish. Indian J. Pharmacol. 2015, 47, 195-198. [CrossRef] [PubMed] 